\title{
The roles of FGFs in the early development of vertebrate limbs
}

\author{
Gail R. Martin ${ }^{1}$ \\ Department of Anatomy and Program in Developmental Biology, School of Medicine, University of California \\ at San Francisco, San Francisco, California 94143-0452 USA
}

"Fibroblast growth factor" (FGF) was first identified 25 years ago as a mitogenic activity in pituitary extracts (Armelin 1973; Gospodarowicz 1974). This modest observation subsequently led to the identification of a large family of proteins that affect cell proliferation, differentiation, survival, and motility (for review, see Basilico and M oscatelli 1992; Baird 1994). Recently, evidence has been accumulating that specific members of the FGF family function as key intercellular signaling molecules in embryogenesis (for review, see Gol dfarb 1996). Indeed, it may be no exaggeration to say that, in conjunction with the members of a small number of other signaling molecule families [including WNT (Parr and MCMahon 1994), Hedgehog (HH) (Hammerschmidt et al. 1997), and bone morphogenetic protein (BMP) (Hogan 1996)], FGFs are responsible for inducing and/ or regulating the subsequent development of most organs in the vertebrate body.

The purpose of this review is to discuss the functions performed by members of the FGF family in one of the best-studied vertebrate developmental systems-limb formation. It focuses initially on what is known about FGF function in the established limb bud and then discusses the mechanisms by which the signaling centers that control outgrowth and patterning of the established limb bud are formed, emphasizing possible roles played by FGFs in these processes. Finally, it discusses the potential role of FGFs in the induction of limb development. The insights into the requirement for FGF signaling in bone development that have been gained from anal yses of mutations in human and mouse FGF receptor (FGFR) genes will not be discussed, as those studies have been the subject of several recent reviews (Wilkie et al. 1995; Yamaguchi and Rossant 1995; De Moerlooze and Dickson 1997; Webster and Donoghue 1997).

\section{FGF ligand and receptor families}

Initial efforts to purify the factors in brain tissue that stimulated fibroblast proliferation led to the identifica-

1E-MAIL gmartin@itsa.ucsf.edu; FAX (415) 476-3493. tion of two closely related proteins-acidic FGF and basic FGF (now designated FGF1 and FGF2, respectively). With the advent of gene isolation techniques it became apparent that the Fgf1 and Fgf2 genes are members of a large family, now known to be comprised of at least 17 genes, Fgf1-Fgf17, in mammals (see Coulier et al. 1997; McWhirter et al. 1997; Hoshikawa et al. 1998; Miyake 1998). At least five of these genes are expressed in the developing limb (see Table 1). The proteins encoded by the 17 different FGF genes range from 155 to 268 amino acid residues in length, and each contains a conserved "core" sequence of 120 amino aci ds that confers a common tertiary structure and the ability to bind heparin or heparan sulfate proteoglycans (HSPGs) (Zhu et al. 1991; Faham et al. 1996). Although all family members share significant amino acid sequence identity in the core region, the sequences flanking it are general ly poorly conserved. The orthologs of many of the mammalian FGF genes have been identified in other vertebrate species, and recently, FGF family members have been identified in worms (Burdine et al . 1997, 1998) and flies (Sutherland et al . 1996). Consistent with their potential functions as intercellular signaling molecules, many of the FGFs are exported efficiently from the cells that produce them. Once released from cells, FGFs bind avidly to HSPGs such as the syndecans, glypican, and perlecan on the cell surface and in the extracellular matrix (ECM), which is thought to restrict their ability to diffuse very far from the cells that produced them (for review, see Basilico and Moscatelli 1992).

The binding of FGFs to HSPGs (sometimes termed low-affinity FGFRs) facilitates FGF signal transduction by oligomerizing and presenting the ligands to high-affinity FGFRs (Faham et al. 1996; for review, see Mason 1994), which are transmembrane protein tyrosine kinases. In vertebrate species, a family of four genes, FgfrlFgfr4, encodes such high-affinity FGFRs, each of which is capable of producing a variety of receptor RNA isoforms through alternative splicing (for review, see Johnson and Williams 1993). Two of these genes apparently play a role in early limb development (Deng et al. 1997; Xu et al. 1998; see Table 1). The binding of FGFs 
Table 1. Expression domains of FGF and FGFR genes in the developing limb

\begin{tabular}{|c|c|c|c|}
\hline $\begin{array}{l}\text { Family } \\
\text { member }^{a}\end{array}$ & Established limb bud ${ }^{\mathrm{b}}$ & $\begin{array}{l}\text { Prospective } \\
\text { limb territory }\end{array}$ & References \\
\hline $\begin{array}{l}\text { Fgf2 } \\
\text { (basic FGF) }\end{array}$ & $\begin{array}{l}\text { throughout AER and dorsal } \\
\text { ectoderm, distal and dorsal } \\
\text { mesenchyme in chick limb buds } \\
\text { not detected in mouse limb buds }\end{array}$ & $\begin{array}{l}\text { ectoderm and } \\
\text { mesoderm }\end{array}$ & $\begin{array}{l}\text { Savage and Fallon (1995) } \\
\text { Chan et al. (1995) }\end{array}$ \\
\hline $\begin{array}{l}\text { Fgf4 } \\
\qquad(\mathrm{Hst}-1 ; \mathrm{kFGF})\end{array}$ & $\begin{array}{l}\text { AER, initially restricted to the } \\
\text { distal and posterior region, and } \\
\text { later throughout the AER }\end{array}$ & N.D. & $\begin{array}{l}\text { N iswander and M artin (1992); Suzuki et al. } \\
\text { (1992); Drucker and Goldfarb (1993); Laufer et } \\
\text { al. (1994); N iswander et al. (1994); Vargesson } \\
\text { et al. (1997) }\end{array}$ \\
\hline $\begin{array}{l}\text { Fgf8 } \\
\text { (AIFG) }\end{array}$ & throughout AER & ectoderm & $\begin{array}{l}\text { Heikinheimo et al. (1994); Ohuchi et al. (1994); } \\
\text { Crossley and M artin (1995); M ahmood et al. } \\
\text { (1995a); Crossley et al. (1996); Vogel et al. } \\
\text { (1996) }\end{array}$ \\
\hline $\begin{array}{l}\text { Fgf9 } \\
\text { Fgf10 }\end{array}$ & $\begin{array}{l}\text { throughout AER } \\
\text { distal mesenchyme }\end{array}$ & $\begin{array}{l}\text { N.D. } \\
\text { mesoderm }\end{array}$ & $\begin{array}{l}\text { D. Ornitz and M. Goldfarb (pers. comm.) } \\
\text { Ohuchi et al. (1997); Xu et al. (1998) }\end{array}$ \\
\hline $\begin{array}{l}\text { Fgfr1 } \\
\quad(\text { Flg) }\end{array}$ & throughout mesenchyme & mesoderm & Orr-U rtreger et al. (1991); Peters et al. (1992) \\
\hline $\begin{array}{l}\text { Fgfr2 } \\
\text { III b isoform (KGFR) } \\
\text { IIIc isoform (Bek) }\end{array}$ & $\begin{array}{l}\text { throughout ectoderm } \\
\text { low levels in mesenchyme }\end{array}$ & $\begin{array}{l}\text { ectoderm and } \\
\text { mesoderm } \\
\text { (possibly no } \\
\text { tissue-specificity } \\
\text { of isoform } \\
\text { expression) }\end{array}$ & $\begin{array}{l}\text { Orr-Urtreger et al. (1991); Peters et al. (1992); } \\
\text { Orr-Urtreger et al. (1993); Xu et al. (1998) }\end{array}$ \\
\hline
\end{tabular}

There appears to have been sufficient analysis to conclude that the following FGF and FGFR genes are not expressed in the devel oping limb, except when associated with muscle cells, cartilagenous condensations, or cells in the most proximal region of the limb bud at late stages: Fgf3 (Wilkinson et al. 1988, 1989; Mahmood et al. 1995b); Fgf5 (Haub and Goldfarb 1991); Fgf6 (de Lapeyrière et al. 1993; Han and M artin 1993); Fgf7 (M ason et al. 1994); Fgf15 (M cWhirter et al. 1997); Fgf17 (Hoshikawa et al. 1998; D. Ornitz, pers. comm.); Fgfr3 (Peters et al. 1993); Fgfr4 (Stark et al. 1991; see also Marcelle et al. 1994).

a(Other designations for gene or protein).

bExcluding expression associated with muscle cells or cartilagenous condensations.

${ }^{\mathrm{c}}$ (N.D.) $\mathrm{N}$ ot detected.

activates the high-affinity receptor proteins by inducing the formation of receptor homo- or heterodimers, which results in receptor transphosphorylation and leads to the activation of a RAS-dependent intracellular signal transduction pathway (for review, see Fantl et al. 1996). FGFRs can also be activated by ligands other than FGFs (for review, see Green et al. 1996), but the biological significance of those findings is not known. Also, it remains to be determined how the activation by different FGFRs of a common signal transduction pathway results in a multiplicity of cellular responses.

The specificity of FGF binding to FGFRs is determined by sequences in the extracell ular domain of the receptor proteins, particularly in a region close to the transmembrane domain containing an immunoglobulin-like loop (termed Ig-loop III) that can be varied by alternative spl icing (for review, see Johnson and Williams 1993). When assayed in vitro, individual FGFR proteins bind multiple FGFs but also display a unique pattern of affinities for the different ligands (for review, see De M oerlooze and Dickson 1997). However, as ligand binding is al so greatly influenced by the distribution of HSPGs at the cell surface and in the ECM , it is unknown to what extent these in vitro assays reflect the ligand binding specificity of different FGFR proteins in vivo.

\section{Signaling centers in the established limb bud}

Much of what is known about the early stages of vertebrate limb development has been learned from experimental studies of the chick embryo, which is manipulated in ovo easily. However, genetic studies in the mouse have provided important insights into the roles played by specific genes in limb development, and comparative studies of gene expression and function during chick and mouse limb development have served to demonstrate that the basic mechanisms of limb formation have been evolutionarily conserved. The description of limb development that follows is a composite of information from studies of both chick and mouse embryos.

Limb development is heralded by the protrusion from the lateral body wall of a small "bud," which is comprised of lateral plate mesoderm (LPM) cells and the overlying surface ectoderm (Fig. 1A). The mesenchymal cells in this bud proliferate and eventually give rise to the skel etal elements and other connective tissue of the mature limb, whereas the li mb muscles are derived from cells that migrate into the limb bud from the somites (Chevallier et al. 1977; Christ et al. 1977). As development proceeds the limb elongates along its proximaldistal (P-D) axis (shoulder to fingers), becomes flattened 


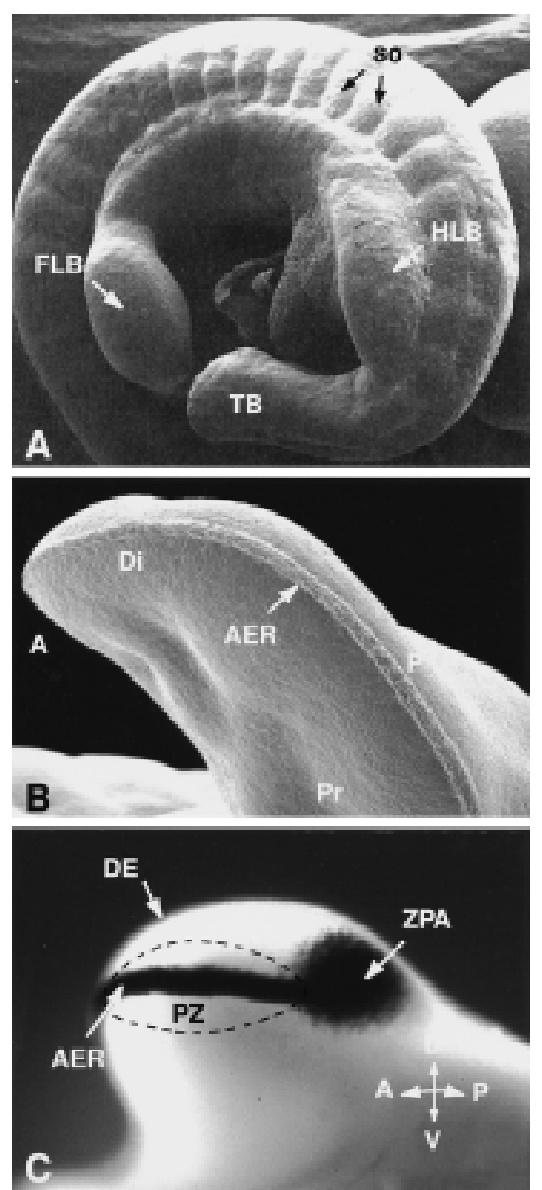

Figure 1. A natomy of the developing limb bud. (A) Scanning EM of a mouse embryo at E10 (lateral view) shows the protrusion from the lateral body wall of the nascent hindlimb bud (HLB). The forelimb bud (FLB), which began its development at an earlier stage (E9.0-E9.5), is larger than the HLB. The somites (so) and tail bud (TB) are readily visible. Reprinted, with permission, from Martin (1990). (B) Scanning EM of a chick hindlimb bud (ventrolateral, posterior view) at stage 24 , showing the distinctive morphology of the AER, which runs along the distal margin of the bud. Photo courtesy of G. Schoenwolf (U niversity of Utah, Salt Lake City). (C) A ventrolateral, posterior view of an establ ished chick limb bud at stage 23, showing the locations of the three major signaling centers that control outgrowth and patterning of the limb: dorsal ectoderm (DE); apical ectodermal ridge (AER); and zone of polarizing activity (ZPA). The AER is marked by expression of Fgf8. The ZPA, which is localized in the mesenchyme just proximal to the posterior end of the AER, is marked by the expression of Shh. The dashed oval indicates the location of the progress zone (PZ) in the mesenchyme subadjacent to the AER, which contains the stem cell population that gives rise to limb skel etal elements in response to signals from the DE, AER, and ZPA. Photo courtesy of P. Crossley (University of California, San Francisco).

along its dorsal-ventral (D-V) axis (back of hand to palm), and asymmetric al ong its anterior-posterior (A-P) axis (thumb to little finger). Differentiation becomes morphologically apparent as the mesenchymal cells condense to form the primordia of individual skeletal ele- ments. The most proximal element, designated the stylopod, begins to differentiate first, with its proximal end forming before the distal end, followed at successively later times by the progressive differentiation of more distal structures (zeugopod and autopod; see Fig. 2A).

Such outgrowth and patterning depends on the establishment and maintenance of three discrete signaling centers within the limb bud: (1) the apical ectodermal ridge (AER or ridge), a morphologically distinct epithelium that runs from anterior to posterior at the distal margin of the bud (Fig. 1B); (2) the zone of polarizing activity (ZPA or polarizing regi on) in the mesenchyme at the posterior margin of the bud, which has no distinguishing morphological features; and (3) the nonridge ectoderm of the bud (Fig. 1C). The functions of the signals from these regi ons have been determined by experimental studies in the chick. Elimination of the AER results in a failure of subsequent P-D outgrowth (Saunders 1948; Summerbell 1974) (see Fig 2B), indicating that signals from the ridge are continuously required for outgrowth of the limb. However, these signals per se do not provide the P-D patterning information that functions to shape the limb skeletal elements (Rubin and Saunders 1972). Grafting the ZPA to the anterior side of a host limb bud results in mirror-image duplication of the posterior limb, indicating that signals from the ZPA regulate patterning along the limb A-P axis (Saunders and Gasseling 1968). Rotation of limb bud ectoderm through $180^{\circ}$ results in a reversal of only D-V polarity, at least of the distal part of the experimental limb (MacCabe et al. 1974; Pautou 1977), indicating that signals from the nonridge ectoderm regulate patterning al ong the limb D-V axis.

Some of the secreted molecules responsible for the activities of the different limb bud signaling centers have been identified. As discussed bel ow, FGFs produced by $A E R$ cells perform the functions of the ridge that are required for $\mathrm{P}-\mathrm{D}$ outgrowth. Sonic hedgehog $(\mathrm{SHH})$ produced by ZPA cells is the key mediator of the polarizing activity that regulates patterning along the A-P axis (Riddle et al. 1993; Chang et al. 1994). WNT 7A, produced by dorsal ectoderm cells and acting through its downstream target gene Lmxl expressed in the underlying mesenchyme, plays a role in patterning along the $D-V$ axis (Parr and M cM ahon 1995; Riddle et al. 1995; Vogel et al. 1995). It is possible that the ventral ectoderm al so secretes a signaling molecule involved in D-V patterning, but as yet no candidate signal has been identified. Importantly, these signals are interdependent. There are regulatory interactions among the different signaling centers, and their products work cooperatively to regulate and coordi nate limb outgrowth and patterning al ong all three axes. For example, as discussed below, FGFs from the ridge and WNT 7A from the dorsal ectoderm are required to maintain Shh expression (and, hence, ZPA activity), and $\mathrm{SHH}$ in turn influences FGF gene expression in the ridge.

These signals act on a population of undifferentiated mesenchymal cells located in a region known as the "progress zone," situated near the distal tip of the limb 


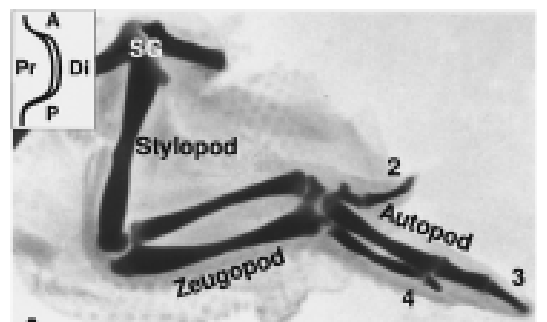

A
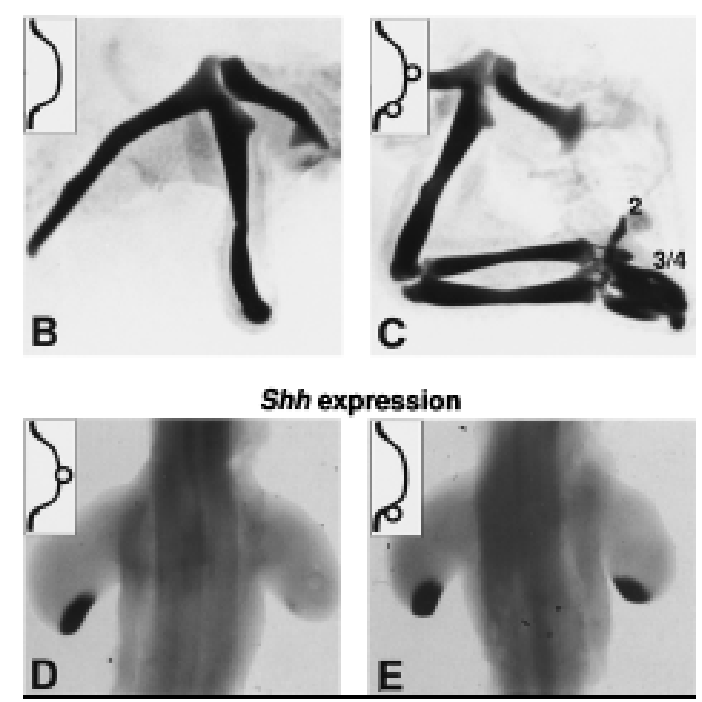

Figure 2. FGF beads can perform the functions of the AER. The inset at the top left of $A-E$ shows a dorsal view of the chick limb bud [(A) Anterior; (Di) distal; (P) posterior; $(\mathrm{Pr})$ proximal ], illustrating the experimental manipulation performed: $(A) N$ one; $(B)$ removal of the AER; AER removal followed by application of two FGF4 beads, one to distal and one to posterior (C); one to distal (D); or one to posterior mesenchyme (E). (A) The skel eton of a normal chick forelimb, illustrating the three major subdivisions of the vertebrate limb: stylopod (humerus in the fore limb, femur in the hindlimb); zeugopod (radius and ulna in the forel imb, ti bia and fibula in the hindli imb); and autopod [carpals, metacarpals, and phalanges (which comprise the digits) in the forelimb, tarsals, metatarsals, and phalanges in the hindlimb]. The chick forelimb autopod contains only three digits, which are numbered 2, 3, and 4 in A to $P$ sequence. (SG) Shoulder girdle. (B) Following removal of the AER at stage 20, the limb that develops contains only the stylopod. However, if FGF4 beads are applied to the exposed mesenchyme as illustrated (C), the limb that develops contains stylopod, zeugopod, and autopod, including digits. The experimental limbs display some abnormalities, including duplication along the D-V axis of the posterior digits (labeled 3/4). Reprinted, with permission, from $\mathrm{N}$ iswander et al. (1993). These data demonstrate that FG F beads can substitute for the AER to provide the signals required for virtually complete outgrowth and patterning of the limb. (D) Following AER removal and application of an FGF4 bead to the distal-exposed mesenchyme, Shh expression is not maintained (cf. experimental limb at right with control limb at left). However, when the FGF4 bead is applied to the posterior-exposed mesenchyme (E), Shh expression is maintained. Reprinted, with permission, from $\mathrm{N}$ iswander et al. (1994). These data illustrate that one of the functions of FGFs produced in the AER is to maintain Shh expression in the ZPA. bud, subadjacent to the AER (see Fig. 1C). As the progress zone cell population proliferates and the limb elongates, some of the cells are left behind (proximal to) the progress zone and are therefore no longer exposed to the signals produced by the AER. To account for the mechanism by which cells are patterned al ong the P-D axis, Summerbell et al. (1973) proposed that time of exit from the progress zone determines cell fate. Time spent in the progress zone might be measured in terms of the number of divisions a cell has undergone, or perhaps in relation to a molecular clock based on the total amount of AERderived signal to which it has been exposed. While they are in the progress zone, cells are also receiving the signals that confer A-P and D-V positional information, which help to determine precisely what structures they ultimately form. Despite the advances in identifying the molecules produced by the different limb bud signaling centers, the molecular mechanism by which progress zone cells interpret such signals is unknown.

\section{FGF function in the established limb bud}

As noted above, the AER is essential for limb outgrowth, and its position and size are critical determinants of limb form. For example, when the AER is rotated $90^{\circ}$, outgrowth takes place at right angles to the origi nal axis and conforms to the new position of the AER (Zwilling 1956). Moreover, the dimensions of the AER seem to determine the number of digits that develop, as the formation of supernumerary digits along the A-P axis is al ways correlated with an increase in the A-P length of the ridge (see, e.g., Goetinck and Abbott 1964; M acCabe et al. 1975; Lee and Tickle 1985). Of the 17 known FGF genes, 5 are expressed in the distal part of the established limb bud (see Table 1), 4 in the AER (Fgf2, Fgf4, Fgf8, Fgf9; e.g., see Fig. $1 C$ ), and 2 in the mesenchyme underlying it (Fgf2, Fgf10), and their role is apparently to provide $A E R$ function, either directly or indirectly.

\section{FGFs perform the functions of the AER}

The many genes expressed in the AER include members of several different families that encode secreted signaling molecules. Given the potential complexity of AER function and the variety of possible candidate molecules that might perform its functions, it cameas somewhat of a surprise when it was first discovered that an individual FGF protein could substitute for the AER. Thus, when heparin beads soaked in recombinant FGF protein (FGF beads) were applied to the exposed limb bud mesenchyme following AER removal at early stages of chick limb development in ovo, the limbs that subsequently formed were essentially normal ( $N$ iswander et al. 1993; Fallon et al. 1994). For example, when two FGF4 beads were applied simultaneously, $\sim 80 \%$ of the limbs developed a full complement of skeletal elements including the autopod, whereas most control limbs failed to form both the zeugopod and autopod ( $\mathrm{N}$ iswander et al. 1993; see Fig. 2C).

The observation that the proteins encoded by at least 
three of the FGF genes expressed in the AER, FGF2 (FalIon et al. 1994), FGF4 (N i swander et al. 1993), and FGF8 (Vogel et al. 1996), can each substitute for the AER in ovo, raises the possibility that all the FGFs produced in the AER contribute to AER function, perhaps by each providing a fraction of the total FGF required. Thus, application of any one FGF protein might rescue development of a ridgel ess limb when it is supplied in a quantity equal to or greater than the total amount of all FGFs normally produced in the AER. Although all FGF genes expressed in the AER may contribute to its function, recent studies have shown that embryos homozygous for null alleles of either Fgf2 (Ortega et al. 1998; Zhou et al. 1998; R. Dono, G. Texido, R. Dussel, H. Ehmke, and R. Zeller, in prep.) or Fgf9 (D. Ornitz, pers. comm.) have normal limbs. These results indicate that neither of these genes is required for normal limb formation but do not exclude the possibility that they perform functions that are redundant with those of other FGF genes expressed in the limb bud.

It has not been possible to demonstrate a requirement for either Fgf4 or Fgf8 in limb devel opment by standard genetic methods, because embryos homozygous for null mutations in either of these genes die before the limbs are formed (Feldman et al. 1995; Meyers et al. 1998). However, the problem of the early embryonic lethal ity of Fgf8 mutant embryos has been circumvented in studies employing the Cre/loxP binary system (for review, see Kilby et al . 1993; see al so Gu et al. 1994) to obtain tissuespecific inactivation of Fgf8. By mating mice carrying an Fgf8 allele in which vital exons of the gene are "floxed" (flanked by loxp sites, the recognition sites for Cre recombinase) (Meyers et al. 1998) to mice carrying a cre gene expressed specifically in the AER, it has been possible to obtain embryos in which all functional Fgf8 gene expression has been eliminated from the AER by embryonic day (E)10.5 ( 35 somites) (M. Lewandoski, E. M eyers, Y.-H. Liu, R. Maxson, and G. Martin, unpubl.). The mutant animals display consistent skeletal abnormalities in both forelimbs and hindlimbs, including loss of digits. The data provide evidence that Fgf8 gene function in the AER is necessary for normal limb development but suggest that other FGF genes are also required. Further studies, including AER-specific inactivation of Fgf4, should hel $p$ to elucidate the requirements for FGF gene function in the ridge. It will also be important to determine what functions are performed by other (non-FGF) genes in the AER.

\section{Specific functions of FGFs produced in the AER}

There is substantial evidence that FGFs produced in the AER serve at least two major functions. One function is to stimulate the proliferation of cells in the progress zone and thus produce the new cells required for limb outgrowth. Studies employing markers for cell prol iferation have directly demonstrated that FGFs are mitogens for limb bud mesenchyme (Aono and Ide 1988; N iswander and Martin 1993; N iswander et al. 1993; Dealy et al. 1997). M oreover, ectopic expression of Fgf2 on the ante- rior side of the wing bud apparently causes excess proliferation of mesenchymal cells, resulting in abnormal thickening and splitting of the skeletal primordia (Riley et al. 1993). Although in vitro studies have suggested that the ability of FGFs to promote the outgrowth of limb mesenchyme is dependent on IGF-I (Dealy et al. 1996), limb development is not specifically affected in mice that lack functional I gfl and I gfl I genes (Liu et al. 1993), thus indicating that IGF signaling is not required for any aspect of normal limb development. There is al so evidence that FGFs are required, in conjunction with $\mathrm{SHH}$ protein, to activate the expression of Hox genes and Bmp2 in the mesenchyme (Laufer et al. 1994; N iswander et al. 1994), but this function may be related to their effects on cell proliferation (Duboule 1995; Ohsugi et al. 1997).

A nother major function of FGFs produced in the AER is to maintain Shh expression in the ZPA. Initial studies of this FGF function relied on assays for polarizing activity that involved transplanting cells from the posterior side of an experimental limb bud to the anterior side of a host limb bud and assessing their ability to induce posterior skeletal duplications. This type of analysis demonstrated that polarizing activity was lost following AER removal but that it was maintained when an FGF bead was appl ied to the ridgel ess posteri or limb bud mesenchyme (N iswander et al. 1993; Vogel and Tickle 1993). After $\mathrm{SHH}$ was identified as the key mediator of polarizing activity, several FGFs were shown to be capable of substituting for the AER to maintain Shh expression (Laufer et al. 1994; Niswander et al. 1994; Crossley et al. 1996; Vogel et al. 1996; Ohuchi et al. 1997) (Fig. 2D,E).

Such experiments leave open the question of which FGFs maintain the ZPA in the normal limb bud. The available evidence indicates that although FGF4 is not required to induce the expression of Shh, it is I argely, but perhaps not exclusively, responsible for mai ntaining Shh expression as the limb elongates. Thus, in the limb buds of mouse embryos homozygous for mutant alleles of the limb deformity (Id) gene, which fail to express Fgf4, Shh RN A is detected at early stages of limb bud devel opment (up to E10.5) but, subsequently, is detected at very low levels or not at all (Chan et al. 1995; Haramis et al. 1995; Kuhlman and Niswander 1997). However, because the level of Fgf8 expression is reduced in the Id mutant AER, the loss of Shh expression may not be due solely to the absence of FGF4. It has yet to be determined whether Shh levels are reduced following loss of Fgf8 function in the AER.

The dependence of Shh expression on FGFs produced in the AER provides an explanation for the observation that as the limb elongates, the ZPA is always located near the ridge. However, it is not known whether the ZPA is comprised of a stable cell population, which always remains distal because cells exiting from the progress zone move proximal to it, or whether it is a transient cell population, which is continuously recruited from the posterior progress zone and ceases to express Shh as it is displaced proximally. The observation that cells proximal to the ZPA can be induced to express Shh in 
response to an FGF bead has been interpreted as reflecting a reactivation of Shh gene expression in cells that had left the ZPA (Yang and N iswander 1995) and thus supporting the hypothesis that the ZPA is a transient cell population. However, conclusive evidence on this point will require a cell lineage analysis.

It is possible that the regulatory interactions between Fgf4 and Shh are reciprocal, as ectopic expression of Shh in the anterior mesenchyme leads to ectopic expression of Fgf4 expression in the overlying anterior AER. Thus, it has been proposed that in the normal limb bud, $\mathrm{SHH}$ produced in the ZPA initially induces and subsequently maintains Fgf4 expression in the A ER (Laufer et al. 1994; $\mathrm{N}$ iswander et al. 1994), perhaps via Bmp2 (Duprez et al. 1996). Consistent with this hypothesis, it has been found that although an AER forms in the limb buds of mouse embryos homozygous for a null allele of Shh, it does not express Fgf4 (Chiang et al. 1996; C. Chiang, pers. comm.). Interestingly, Fgf8 is expressed in the AER of Shh mutant limb buds, supporting the hypothesis that Fgf8 functions upstream of Shh (see below). A positive feedback loop between Fgf4 and Shh provides one mechanism by which outgrowth and patterning of the limb could be coordinately regulated, but it is important to bear in mind that other secreted signaling molecules, such as WNT 7A produced by the dorsal ectoderm, may also play a role in regulating Shh expression (Parr and McMahon 1995; Yang and N iswander 1995).

In addition to Shh, there are a large number of genestoo many to discuss here-whose expression in the limb bud mesenchyme is maintained by FGF signaling from the AER. Several of these are transcription factors that may play an important role in interpreting the early patterning signals and initiating the cascade of gene expression that ultimatel y resul ts in the devel opment of a limb (for review, see Tickle and Eichele 1994). One of the challenges for future studies is to determine which of these genes is directly regulated by FGFs from the AER and how they function to maintain limb outgrowth and patterning.

Function of FGF10 produced in the limb bud mesenchyme

Fgf10 is one of the genes expressed in the distal limb bud mesenchyme that may be a di rect target of FGF signaling from the AER (Ohuchi et al. 1997). As discussed below, Fgf10 is thought to play a key role at very early stages of limb development, prior to the development of the AER. In the established limb bud, Fgf10 expression, which is normally detected at high levels in the distal mesenchyme, is no longer observed $10 \mathrm{hr}$ after ridge removal. Implants of Fgf8-expressing cells can rescue Fgf10 expression. On the basis of these observations, as well as the finding that Fof10-expressing cells can induce both Fgf8 expression and thickening of nonridge ectoderm, Ohuchi et al. (1997) have proposed that there may be a positive feedback loop between Fgf8 and Fgf10, si milar to the one proposed for Fgf 4 and Shh. M oreover, they have suggested that FGF10 might be the factor produced by the distal mesenchyme that serves to maintain the AER, that is, the "AER maintenance factor," the existence of which has been inferred from classic embryological studies in the chick embryo (for review, see Hinchliffe and Johnson 1980).

\section{Formation of the ZPA and AER}

Knowledge of the molecules and cellular mechanisms involved in forming the signaling centers present in the established limb bud is crucial to understanding limb development. In the chick, ZPA formation, as reported by Shh expression, begins at approximately the same stage as outgrowth of the limb bud first becomes evident. A few hours later, morphogenetic changes occur in the surface ectoderm, resulting in the formation of the AER, which contains cells that are both morphologically and molecularly distinct from nonridge ectoderm cells. Several lines of evidence suggest that FGF genes, particuIarly Fgf8 and Fgf10, play a role in mediating the initial outgrowth of the limb and in establishing the ZPA and AER.

\section{Initiation of limb bud outgrowth}

The bulge in the lateral wall of the embryo that marks the onset of limb bud formation results from the continual proliferation of cells in the prospectivelimb-forming region and a concomitant decrease in cell proliferation elsewhere along the length of the LPM (Searls and Janners 1971). Because FGF8 can stimulate outgrowth of the LPM (Mahmood et al. 1995a; Crossley et al. 1996; Vogel et al. 1996) and is expressed before limb bud outgrowth is evident, it has been proposed that FGF8 produced in the surface ectoderm functions to maintain the proliferation of the LPM in the prospective limb-forming regions. This hypothesis is supported by the observation that there is no expression of Fgf8 in the prospective limb ectoderm and no initiation of limb bud outgrowth in mouse embryos homozygous for a mutant allele of Fgfr2 (Xu et al. 1998). However, in limbless mutant chick embryos there is apparently normal initial outgrowth of the limb bud in the absence of Fgf8 expression in the ectoderm (Grieshammer et al. 1996; N oramly et al. 1996; Ros et al. 1996). This observation provides evidence that FGF8 is not required, at least in the limbless mutant, for the initial phase of limb bud outgrowth but does not exclude the possibility that FGF8 contributes mitogenic activity in the normal limb bud.

Based on its expression pattern, the Fgf10 gene is a candidate for stimulating early limb bud outgrowth. At early stages of development Fgf10 expression is detected widely in the LPM but then is down-regulated in the interlimb region and becomes restricted to the mesoderm of the prospective forelimb and hindlimb territories just prior to the start of limb bud outgrowth (Ohuchi et al. 1997). However, there is evidence suggesting that FGF10 acts through an FGFR2 isoform (IIIb) that is expressed, at least at later stages of development, by epithelial rather than mesenchymal cells (see Ohuchi et al. 
1997; Xu et al. 1998). Further studies are required, including inactivation of Fgf 10 in the prospective limb bud mesoderm and Fgf8 in the overlying ectoderm, to directly determine the roles of these and other genes in regulating the initial outgrowth of the limb bud.

\section{Formation of the ZPA}

An important issue in early limb development is how the ZPA is established and localized to the posterior limb bud (for review, see Johnson and Tabin 1997). Just prior to the stage at which limb bud outgrowth begins in the chick embryo, polarizing activity (competence to express Shh and thus form a ZPA) is detected not only in prospective posterior limb territory but al so in the interlimb region (Hornbruch and Wolpert 1991; Stratford et al. 1997). It appears that the clustered Hox genes, such as Hoxb8, have a role in providing such competence to express Shh (Charité et al. 1994; Lu et al. 1997; Stratford et al. 1997). However, there is substantial evidence that in the competent regions FGF signaling is necessary to induce Shh expression, and that during normal limb development FGf8 is the specific family member that serves as the required FGF.

This conclusion is based on several findings. Fgf8 is expressed prior to Shh expression during the development of both normal and ectopic limb buds (Crossley et al. 1996; Vogel et al. 1996). In either Fgfr2 ${ }^{\Delta l g l l \prime}$ (Xu et al. 1998) or limbless (Grieshammer et al. 1996; N oramly et al. 1996; Ros et al. 1996) mutant embryos, which fail to express Fgf8, no Shh is detected. Moreover, FGF8 can induce Shh expression in limbless limb buds (Grieshammer et al. 1996). Taken together, these data indicate that FGF8 produced in the surface ectoderm has a role in inducing Shh expression in the underlying mesoderm and that restriction of Fgf8 expression to the prospective limb ectoderm serves to restrict ZPA formation to the prospective limb mesenchyme. The posterior restriction of Shh expression within the nascent limb bud is due either to a lack of competence in the anterior limb bud mesenchyme to respond to FGF8 produced in the overlying ectoderm or to the presence of a repressor of Shh expression (for review, see Johnson and Tabin 1997; see also Qu et al. 1997).

\section{Localization of the prospective AER}

The data discussed above emphasize the importance for normal limb development of appropriately restricting Fgf8 expression specifically to the ectoderm of the prospective limb territory. It has long been assumed that the AER, for which Fgf8 is an early molecul ar marker, forms at the boundary between dorsal and ventral territories, but until relatively recently there was no means of confirming this assumption or exploring the molecular mechanism by which the prospective site of AER formation is determined. This problem has been solved to some extent by the identification of markers for $D-V$ polarity in the developing limb bud.
Wnt7a (Dealy et al. 1993; Parr et al. 1993) and En1 (Davis et al. 1991), a vertebrate homolog of the Drosophila transcription factor gene engrailed, are expressed in the dorsal and ventral ectoderm of the established limb bud, respectively. Expression of both genes is initially detected prior to formation of the AER, and both are required for normal $\mathrm{D}-\mathrm{V}$ patterning of the distal limb (Parr and M CM ahon 1995; Loomis et al. 1996; Cygan et al. 1997; Loomis et al. 1998). Using these two genes as markers, it has not only been confirmed that the AER is located at the $\mathrm{D}-\mathrm{V}$ boundary of the limb bud, but it has also been shown that the AER itself is divided into a dorsal domain in which neither Wnt7a nor En1 are expressed, and a ventral one in which En1 is expressed (Fig. $3 A, B)$. As yet, genes specifically expressed in the dorsal AER have not been identified.

Wnt7a and En1 have al so been useful as markers for demonstrating that the mechanism by which Fgf8 expression is induced in the prospective limb ectoderm is in some way linked to the establishment of normal D-V polarity. Thus, it has been found that in embryos homozygous for the chick limbless mutation there is both a failure to express Fgf8 in the limb bud ectoderm and a lack of normal D-V polarity (Grieshammer et al. 1996; N oramly et al. 1996; Ros et al. 1996). A relationship between AER formation and D-V polarity is further demonstrated by the observations that transplantation of prospective dorsal tissue into ventral limb domains, or vice versa, results in the formation of an ectopic AER (Tanaka et al. 1997), and replacing patches of dorsal ectoderm with ventral ectoderm leads to ectopic expression of Fgf8, presumably at the border between host dorsal and graft ventral tissue (Laufer et al. 1997).

Ectopic gene expression studies in the chick have suggested that it is not apposition of dorsal and ventral territories per se that is required to induce AER formation, as suggested previously by M einhardt (1983), but instead that the A ER forms as a consequence of a cascade of gene expression that is induced at the boundary between cells in the dorsal ectoderm that express Radical-fringe ( $R$ fng), one of three vertebrate homologs of the Drosophila fringe gene (Wu et al. 1996; Cohen et al. 1997; Johnston et al. 1997; Sakamoto et al. 1997), and nonexpressing cells in the ventral ectoderm (Laufer et al. 1997; Rodriguez-Esteban et al. 1997). This hypothesis is appeal ing because it suggests that the function of the fringe gene, which plays a key role in the formation of the wing margin required for outgrowth and patterning of the Drosophila wing (for review, see Brook et al. 1997; Irvine and Vogt 1997), has been evolutionarily conserved. By further anal ogy with Drosophila, it has been suggested that $R$-fng may function in AER formation via effects on the Notch signaling pathway (Laufer et al. 1997; RodriguezEsteban et al. 1997). Although the model based on R-fng gain-of-function experiments in the chick is attractive, data from other types of experiments are not consistent with the hypothesis as proposed (for review, see Irvine and Vogt 1997). In the absence of loss-of-function data, a requirement for $\mathrm{R}$-fng function in $A E R$ formation must remain speculative. 

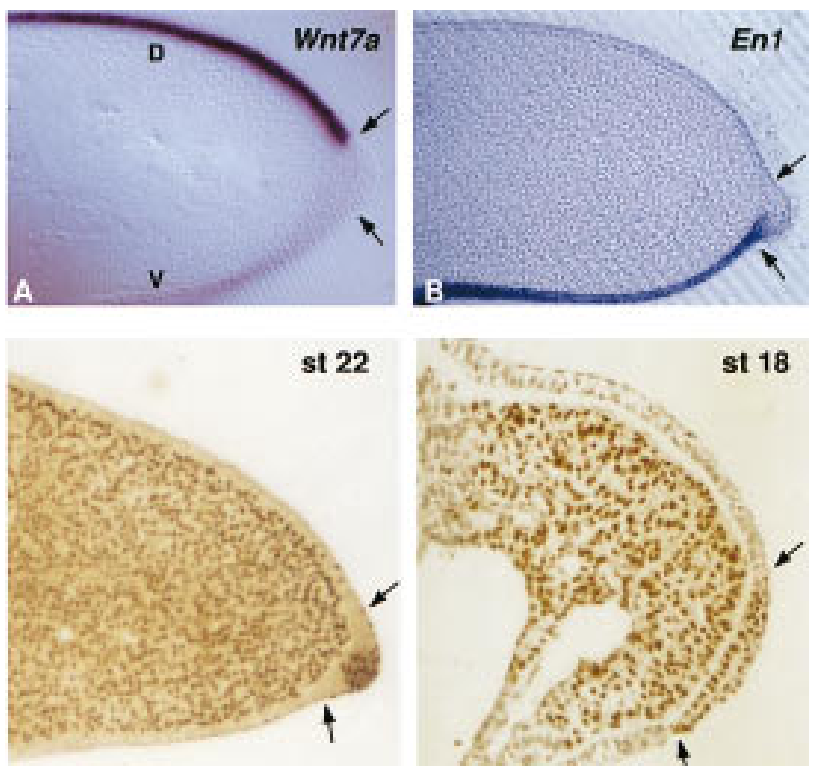

C

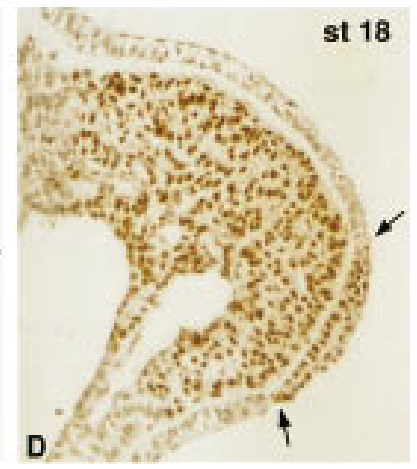

Figure 3. Development of the AER. (A,B) Dorsal and ventral compartments within the AER. Transverse sections of a chick limb bud at stage 21 hybridized with probes for Wnt7a (A) and En1 (B). Arrows demarcate the dorsal and ventral limits of the AER. Wnt7a is expressed throughout the dorsal limb bud ectoderm but not in AER cells. En1 is expressed throughout the ventral limb bud ectoderm and al so in cells in the ventral half of the AER. Reprinted, with permission, from Logan et al. (1997). (C,D) M orphogenesis of the AER. Cells in the prospective limb territory (ectoderm and mesoderm) of a chick embryo at stage 13 were replaced by cells from the corresponding region of a quail embryo, and the grafted embryos were incubated to later stages and then stained with an antibody specific for quail cells (dark brown stain). (C) At stage 22 the quail cells are local ized within the AER (and al so constitute the majority of the limb bud mesenchyme), illustrating that the grafted ectodermal cells are fated to form the AER. (D) At a stage immediately prior to morphogenesis of the AER (stage 18), the quail prospective AER cells are spread throughout the ventral ectoderm (between the arrows). Reprinted, with permission, from Michaud et al. (1997). Analysis of gene expression in chick limb buds at a similar stage of development indicates that the prospective AER cells in the ventral ectoderm express Fgf8 (see Crossley et al. 1996).

\section{Mechanism of AER morphogenesis}

At prelimb bud stages, fate-mapping studies show that AER precursors are widely distributed in prospective limb ectoderm (Altabef et al. 1997; M ichaud et al. 1997). However, by the stage at which morphogenesis of the ridge begins (stage 18 in the chick), most progenitors of the AER appear to be localized primarily along the distal and ventral surface of the nascent limb bud (M ichaud et al. 1997) (Fig. 3C,D). Gene expression studies in both chick and mouse embryos show that just prior to formation of a morphol ogically distinct ridge, cells expressing molecular markers of the AER such as Fgf8, DIx2, and CD 44, are similarly local ized (Crossley and M artin 1995; Crossley et al. 1996; Loomis et al. 1998; S. Bell, C.M. Schreiner, and W.J. Scott, in prep.). The first visible manifestation of ridge morphogenesis in the mouse limb bud is a change in the shape (from flat to cuboidal) of the presumptiveAER progenitors throughout the distal-ventral ectoderm. Subsequently, it appears that they continue to undergo changes in cell shape and to move progressively more distally, so that they ultimately become concentrated in a narrow ridge at the distal margin of the limb bud, which consists of a layer of pseudostratified columnar basal cells and several layers of superficial flattened cells (Milaire 1974; Loomis et al. 1998; S. Bell, C.M. Schreiner, and W.J. Scott, in prep.). In the chick, these morphological changes appear to occur more rapidly than in the mouse, and the AER that forms consists of a pseudostratified basal layer and a single, flattened superficial layer-the periderm (Todt and Fallon 1984).

Loss of Enl function inhibits the process by which the cuboidal AER precursors in the ventral ectoderm change shape and become localized in a narrow ridge (Loomis et al. 1996). On the basis of a detailed analysis of En1 mutant embryos, Loomis et al. (1998) concluded that the cells that form the dorsal domain of the AER (i.e., those that do not express En1) are not inhi bited from undergoing most of the normal events of AER morphogenesis; therefore, a normal dorsal AER forms in the En1 mutant limb bud, whereas the ventral AER progenitor cells remain spread throughout the ventral ectoderm. Interestingly, the En1 mutant limbs display largely normal P-D and A-P outgrowth and patterning, suggesting that prospective ridge cells do not need to form a morphologically normal ridge to perform their functions. On the basis of these observations, it was proposed that the morphogenesis of the normal AER depends on behavioral differences between the progenitors of the dorsal and ventral domains of the AER, and that dorsal prospective $A E R$ cells may stimulate ventral prospective AER cells to move towards them.

An analysis of En1/Wnt7a double mutant embryos (Cygan et al. 1997; Loomis et al. 1998) has led to the suggestion that the proposed dorsal behavior of prospective AER cells is specified by some form of WNT signaling but that Wnt7a is unlikely to be the WNT family member that provides the presumed dorsal izing signal in the normal limb bud. It is also possible that signal ing via the $\mathrm{N}$ otch receptor is in some way involved in specifying the proposed differences between dorsal and ventral prospective AER cells, as the mouse mutation syndactylism, which causes abnormalities in AER morphogenesis, appears to be a hypomorphic allele of Serrate2, a homol og of the Drosophila gene that encodes the $\mathrm{N}$ otch ligand Serrate (Sidow et al. 1997).

Fgf8 expression in prospective AER cells may also have an important role in ridge morphogenesis. Fgf8 RNA is detected in prospective AER cells either just prior to or shortly after they begin to thicken (Crossley and Martin 1995; Crossley et al. 1996; Loomis et al. 1998; S. Bell, C.M. Schreiner, and W.J. Scott, in prep.), although it is not known whether Fgf8 is expressed in all cells that will ultimately form the ridge. On the basis of the recent finding from studies of Fgf8 null mutant mouse embryos that Fgf8 is required during gastrulation 
to enable nascent mesoderm cells to move away from the primitive streak (X. Sun, E. M eyers, M. Lewandoski, and G. Martin, unpubl.), it is tempting to speculate that FGF8 produced in prospective AER cells mediates or facilitates the morphogenetic movements that occur during ridge formation. This cannot be determined from studies of embryos in which Fgf8 has been inactivated after the AER has formed (M. Lewandoski, E. Meyers, Y.-H. Liu, R. Maxson, and G. M artin, unpubl.) but could be studied if Fgf8 were inactivated in the prospective limb bud ectoderm prior to AER formation.

Any molecular model of AER formation should include an "AER inducer," whose presence in the mesoderm of the prospective limb region has been inferred from experimental studies in the chick. Both this inducer in the mesoderm and competence of the overlying ectodermal cells to respond to it are present only transiently (for review, see Hinchliffe and Johnson 1980; see also Carrington and Fal Ion 1984). FGF10 appears to have some activities consistent with a role as the mesodermderived inducer (Ohuchi et al. 1997). Presumably it al one does not perform this function, as AER-inducing activity is not detectable in the established limb bud, whereas Fgf10 continues to be expressed at high levels in the distal limb bud mesenchyme until late stages of limb development. Alternatively, it is possible that FGF10 is itself the mesoderm-derived AER inducer but that an inhibitor of its activity is present at later stages of limb development.

\section{FGF function in limb bud induction}

An important question about limb development is what activates the process and induces the limbs to form where they do. As with other classic examples of embryonic induction, both an inducer and competence to respond to the inducer are necessary to initiate limb development. Remarkably, it has been found that an individual FGF protein is sufficient to induce the formation of a complete limb (Fig. 4A,B). Thus, Cohn et al. (1995) showed that insertion of an FGF bead in the LPM of the interlimb region (often referred to as "the flank") of a chick embryo in ovo results in the formation of an ectopic limb, provided that the bead is applied prior to the stage at which normal limb bud outgrowth begins (stage 17).

\section{FGF-induced ectopic limbs}

A number of FGF family members can induce an ectopic limb, including FGF1, FGF2, FGF4, FGF8, and FGF10 (Cohn et al. 1995; Ohuchi et al. 1995; Crossley et al. 1996; Vogel et al. 1996; Ohuchi et al. 1997), although differences have been observed with respect to the efficiency and the stage specificity of their effects. The significance of these differences is unclear and may be due at least in part to variations in the amount and activity of the FGF protein applied. Importantly, all of the FGFs act by initiating the normal cascade of gene expression that

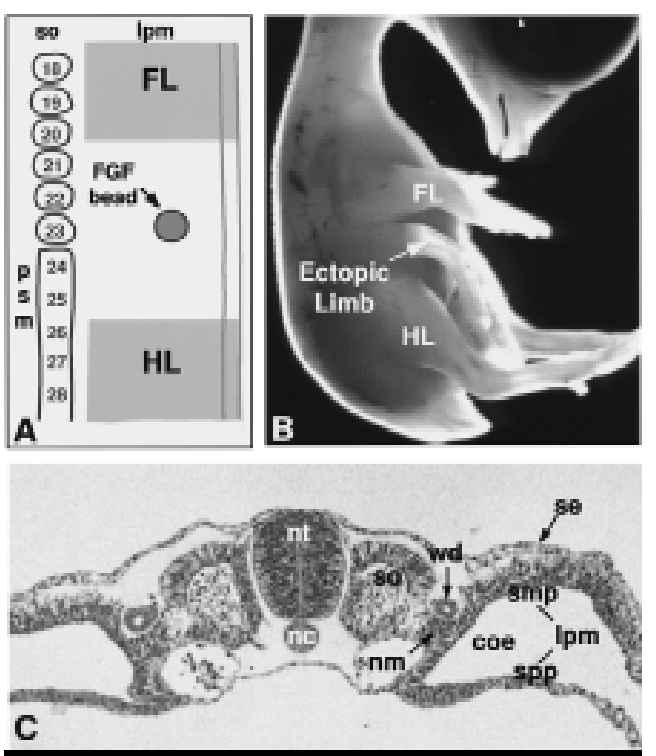

Figure 4. FGF function in limb induction. (A) Schematic diagram illustrating an experimental protocol for inducing an ectopic limb. An FGF bead is inserted into the lateral plate mesoderm (lpm) of a stage 14 chick embryo, in the interlimb region at approximately the level of somite (so) 23, midway between the prospective forelimb (FL) (so 15-20) and hindlimb (HL) (so 26-31) territories. At this stage prospective somites 24-29 are still within the presomitic mesoderm (psm). (B) A chick embryo with an ectopic limb induced by an FGF4 bead (photo courtesy of P. Crossl ey). (C) Transverse section of a chick embryo at stage 14 , at the level of the posterior prospective forelimb territory. The nephrogenic mesoderm $(\mathrm{nm})$, together with Wolffian duct (wd), comprises the intermediate mesoderm, which lies between the somite and the LPM (photo courtesy of L. Prentice, University of California, San Francisco). As discussed in the text, an FGF8 signal from the nephrogenic mesoderm to the adjacent lateral plate mesoderm, which is divided into somatopleure (smp) and spl anchnopl eure (spp) by the coel om (coe), may function to induce the somatopleure and overlying surface ectoderm (se) to form a limb. (nc) $\mathrm{N}$ otochord; (nt) neural tube.

leads to the formation of a limb. Interestingly, an ectopic limb forms only when FGF is applied focally, as, for example, by insertion of an FGF-soaked bead or a pellet of Fgf-expressing cells. The outcome differs when FGF genes are expressed more widely in the interlimb region of the chick (Mima et al. 1995; Vogel et al. 1996) or mouse (A bud et al . 1996) embryo. Although such nonfocal ectopic FGF gene expression results in outgrowth of the interlimb region mesoderm, sometimes in the form of multiple protrusions along the flank of the embryo, the outgrowths eventual ly regress and an ectopic li mb is not formed. It should also be noted that ectopic expression of FGF genes can adversely affect the development of the normal limb, resulting in deletions or reductions and fusions, mainly of the proximal bones, as well as the appearance of extra digits (Vogel et al. 1996).

The ectopic limbs that form in response to focal FGF signaling are often remarkably complete. The type of limb that develops is generally dependent on the loca- 
tion of the FGF source. Sources placed close to the prospective forelimb territory usually induce wings, whereas those placed close to the prospective hindl imb usually induce legs (Cohn et al. 1997). However, careful examination of these limbs has shown that they are mosaics. Thus, the ectopic wings have some features of the leg and vice versa (Ohuchi et al. 1998).

One of the most striking features of the FGF-induced ectopic limbs is that their A-P polarity is opposite that of the normal limb. Thus, at early stages of development, Shh RNA is detected on the anterior rather than the posterior side of the ectopic limb bud, and the pattern of digits that subsequently develops is likewise reversed. One possible explanation for this observation is that within the interlimb region there is an $A$ to $P$ gradient of decreasing competence to express Shh (i.e., polarizing activity) (Hornbruch and Wol pert 1991); therefore, Shh is more likely to be induced on the anterior than on the posterior side of the nascent ectopic limb bud. It is al so noteworthy that the AER of the ectopic limbs always forms at the $\mathrm{D}-\mathrm{V}$ border of the interl imb region (C rossley et al. 1996; Altabef et al. 1997), presumably because the same mechanism that is used to form the AER of the normal limb is employed in the formation of the ectopic limb bud AER.

\section{Source and identity of the endogenous limb inducer}

The experiments showing that FGF beads can induce limb formation in the interlimb region have provided insights into both the nature of the inducer and the availability of competence to respond to it. The finding that FGF protein is sufficient to induce the formation of a complete limb suggests that the endogenous inducer of limb devel opment may likewise be a member of the FGF family. The observation that limbs can be induced to form along much of the length of the embryo suggests that competence to respond to the limb-inducing signal is widespread al ong the $A-P$ axis and that the induction of normal limb formation at specific A-P levels may involve some mechanism for restricting the availability of the inducer.

Information about the stage at which limb induction occurs and the tissue source of the inducer has been obtained using an assay that involves grafting the prospective limb-forming region to an ectopic site in a chick host embryo and then determining whether the graft can develop autonomously into a limb (Kieny 1969; Kieny 1970; Pinot 1970; Stephens et al. 1993). Although there are some discrepancies among the results, they indicate that limb induction has occurred by about stages 13-15 ( 20-25 somites), whereas the first morphological manifestations of limb bud formation do not become apparent until several hours later, at stage 17 ( 30 somites). Prior to stages 13-14, a limb will form only when tissue medial to the prospective limb territory is included in the graft. At stages 8-9, limbs will form only when Hensen's node, somites, and intermediate mesoderm (IM) are included in the graft. At slightly later stages (10-11), only the somites and IM are required, and later still (stages
12-14) inclusion of the IM is sufficient for limb formation by the graft. Thus, the signal for limb induction appears to be transmitted in a medial to lateral sequence.

Data from foil barrier (Stephens and McNulty 1981; Strecker and Stephens 1983) and tissue ablation (Geduspan and Solursh 1992) experiments are consistent with the hypothesis that at stages 13-15, the source of the limb inducer is the IM, which lies between the somite and the lateral plate mesoderm and is comprised of nephrogenic mesoderm (N M) and the Wolffian duct (WD) (Fig. 4C). Like all other tissues that lie along the A-P body axis, the IM undergoes a series of developmental changes in a rostral to caudal sequence. Initially it consists of a small group of undifferentiated NM cells. As development proceeds, the Wolffian duct forms and extends caudally, immediately dorsal to the NM. The duct apparently produces signals that induce the differentiation of the N M (Bishop-Calame 1965; Wolff 1970), which condenses and forms the mesonephric tubules that subsequently fuse with the duct to form the mesonephros, the principal organ of excretion during early fetal life in many species. Eventually the mesonephros degenerates and is functionally replaced by the metanephros (kidney).

Together, the data indicate that limb induction in the chick occurs between stages 13 and 15, that the source of the inducer is most likely the IM, and that a member of the FGF family is a good candidate for the inducer. M oreover, the application of FGF protein to the interlimb region induces limb development, which suggests that the endogenous inducer is not normally present in the interlimb region. On the basis of its expression pattern in the $\mathrm{NM}$ and its ability to induce ectopic limb development, it was suggested that FGF8 is an endogenous inducer of limb development, although the possibility that other FGF family members may have a similar function was not excluded (Crossl ey et al. 1996). Furthermore, on the basis of expression patterns at earlier stages, it was suggested that FGF8 may al so be a component of the limbinducing signals that emanate from more medial tissues at earlier stages (Vogel et al. 1996).

The expression data also raised the possibility that Fgf8 might be regulated by signal s from the WD, suggesting a potential link between the presumed limb inducer and development of the mesonephros (Crossley et al. 1996). However, although experimental manipulations that prevent the duct from extending caudally inhibit mesonephric tubulogenesis, they do not prevent limb development (Le Douarin and Fontaine 1970; FernandezTeran et al. 1997). Thus, if Fgf8 expression in the N M is induced by signals from the duct, it cannot be involved in limb development. This issue was recently explored by Fernandez-Teran et al. (1997), who studied Fgf8 expression in embryos in which caudal extension of the WD was blocked at stages 9-11. They concluded that Fgf8 expression is induced and maintained by signals from the duct. However, results from a similar study by other investigators indicate that Fgf8 expression is detected in the absence of the duct in undifferentiated N M at the level of the prospective foreli mb between stages 13 
and 15; at later stages Fgf8 expression is not detected in the N M (J. Kulhman, G. Kardon, and L. N iswander, pers. comm.). Such data indicate that Fgf8 is initially expressed in the NM irrespective of whether the WD is present but that maintenance of this expression may depend on signals from the duct. Although these results are consistent with the hypothesis that FGF8 functions as the inducer of limb formation, this idea must remain speculative until it can be rigorousl y tested, for example, by inactivating the Fgf8 gene specifically in the N M at a stage prior to limb induction.

Induction of Fgf8 expression in the prospective limb bud ectoderm

An early molecular manifestation of limb induction is the expression of Fgf8 in the prospective limb ectoderm. If an FGF produced in the NM is the limb inducer, then there is presumably some mechanism for transmitting the inducing signal through the LPM to the responding ectoderm (see Fig. 4C), as FGFs are thought to signal only Iocally. It has been proposed that FGF10 may be the mesenchymal mediator of the limb induction signal and thus function as the endogenous inducer of Fgf8 expression in the overlying ectoderm (Ohuchi et al. 1997). Several observations support this idea: (1) In normal limb development, Fgf10 expression in the mesoderm precedes that of Fgf8 in prospective limb ectoderm; (2) when ectopic limbs are induced by FGF8, Fgf10 RN A is detected in the mesenchyme before Fgf8 RN A is detected in the overly- ing ectoderm; and (3) implants of rat Fgf10-expressing cells in the interlimb region induce Fgf8 expression in the overlying ectoderm.

Genetic evidence consistent with the hypothesis that FGF10 produced in the prospective limb mesoderm induces Fgf8 expression in the overlying ectoderm comes from studies of embryos homozygous for Fgfr2 ${ }^{\Delta l \text { glll }}$, a presumed hypomorphic allele of Fgfr2, in which limb development fails at the stage of initial outgrowth (Xu et al. 1998). In the mutant embryos, Fgf10 is expressed in its normal domain in the prospective limb mesoderm but at significantly lower levels than in wild-type embryos, and Fgf8 is not expressed in the prospective limb ectoderm. According to the model proposed by $\mathrm{Xu}$ et al. (1998), the lack of Fgf8 expression may be due to a loss of Fgfr2 function in the surface ectoderm, which prevents the ectodermal cells from receiving the FGF10 signal that normally induces them to express Fgf8. Alternatively, it is possible that the Fgfr2 mutation acts at an earlier stage, interfering with transduction of the limbinducing signal through the prospective limb mesoderm and resulting in the production of FGF10 at levels insufficient to induce Fgf8 expression in the ectoderm. In either case, the absence of Fgf8 expression in the ectoderm can account for the observation that Fgf10 expression gradually diminishes in the underlying mesoderm, presumably because of an interruption in the proposed Fgf8Fgf10 positive feedback loop. Further genetic analysis should hel p to clarify the relationship between these two genes.

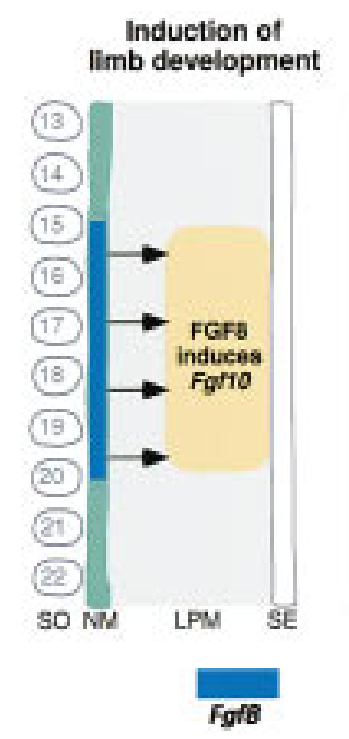

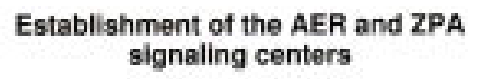
signaling centers

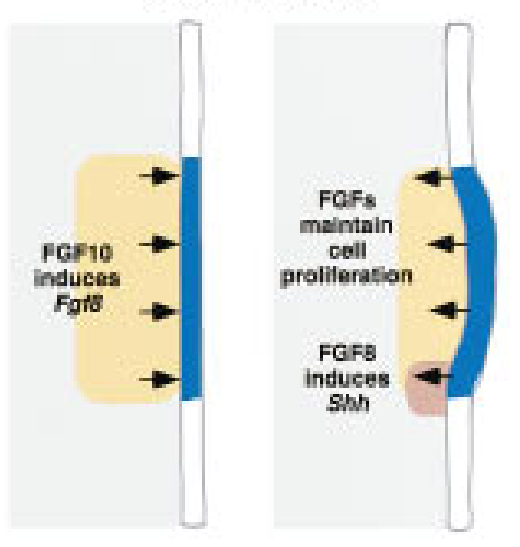

Fgrlo

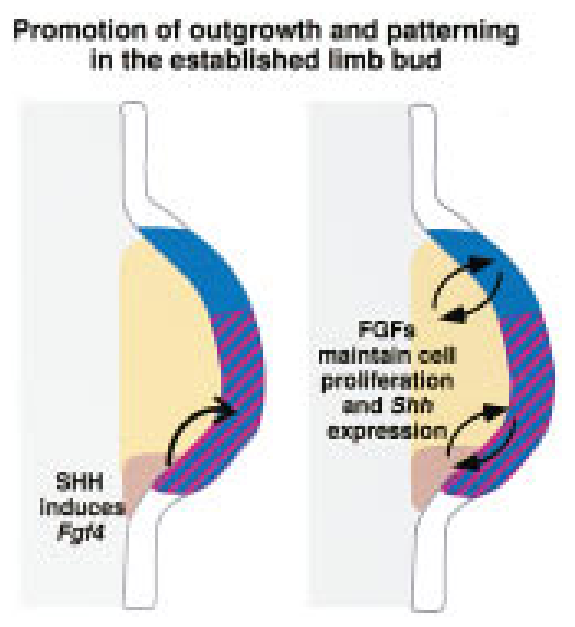

Fof

Figure 5. Possible roles of FGF family members in the induction, initiation, and maintenance of limb development. Diagrams representing dorsal views of the prospective limb territory or limb bud illustrate a speculative model of the roles of FGFs in limb devel opment. FGF8 produced in the N M in the prospective forelimb territory induces the expression of Fgf10 in the adjacent LPM . FGF10 produced in the prospective limb mesoderm then induces Fgf8 expression in the overlying surface ectoderm (SE). FGF8 secreted by the prospective limb ectoderm in conjunction with FGF10 in the mesoderm acts to maintain outgrowth of cells in the LPM . FGF8 also functions to induce Shh expression and thus establish the ZPA. SHH protein produced in the LPM directly or indirectly induces expression of Fgf4 in the overlying ectoderm. In the established limb bud (far right), presumed positive feedback loops between Fgf8/Fgf10 and Fgf4/Shh, indicated by arrows, function to maintain limb development. The role(s) of D-V positional information in limb development are not shown. 


\section{Concluding remarks}

Because the purpose of this article is to review what is known about the role of FGFs in vertebrate limb development, it seems appropriate to concl ude with a diagram that summarizes the presumed functions of different FGF family members at various stages of limb formation (Fig. 5). It should be apparent from the preceding discussion that in most cases conclusive proof is lacking that the specific FGFs indicated in the diagram perform the functions attributed to them, and that other members of the FGF family, either known or yet to be identified, may be responsible for the functions ascribed to a particular FGF. However, most of the existing hypotheses about the functions of specific FGFs are testable and will soon be evaluated, and other questions about FGF signaling, such as the specificity of ligand-receptor interactions in vivo, the extent to which FGF signals can act at a distance from the cells that produce them, and the role of endogenous inhibitors of FGF signaling (Hacohen et al. 1998) will presumably also be resolved. With the combination of classic experimental embryological approaches and contemporary techniques for analyzing gene function in the chick that is currently available, as well as standard and sophisticated new methods of genetic analysis in the mouse, knowledge about the molecular mechanism of vertebrate limb development should continue to accumulate rapidly.

Finally, in view of the extraordinary extent to which developmental mechanisms and the molecules that regulate them have been conserved between invertebrates and vertebrates, it is somewhat surprising that members of the FGF family have not yet been found to play a role in Drosophila limb development. However, the recent identification of an FGF family member in Drosophila (Sutherland et al. 1996), which plays a role in branching of the tracheal system that may be analogous in some respects to the role proposed for FGF10 in budding of vertebrate lung epithelium (Bellusci et al. 1997), suggests that FGF function in the devel opment of many different organs may have been conserved from invertebrates to vertebrates. As knowledge of the molecular mechanism of limb devel opment in Drosophila has informed and influenced many of the recent studies of vertebrate limb devel opment, it would be gratifying if what is known about FGF function in vertebrate limb development were to lead to new insights into the mechanism of Drosophila limb development.

\section{Acknowledgments}

I am very grateful to the many people who provided unpublished information, preprints of manuscripts in press, and helpful discussions, and especially to P. Crossley, C. Logan, J. Michaud, L. Prentice, and G. Shoenwolf for providing photographs used in the figures. I would also like to thank M. Altabef, E. Coucouvanis, C. Loomis, L. N iswander, C. Tabin, C. Tickle, T. Vogt, and the members of my laboratory group for critically reading the manuscript and providing insightful suggestions for improving it.

\section{References}

A bud, H.E., J.A. Skinner, F.J. M cD onal d, M.T. Bedford, P. Lonai, and J.K. Heath. 1996. Ectopic expression of Fgf-4 in chimeric mouse embryos induces the expression of early markers of limb development in the lateral ridge. Dev. Genet. 19: 5165.

Altabef, M., J.D.W. Clarke, and C. Tickle. 1997. Dorso-ventral ectodermal compartments and origin of apical ectodermal ridge in developing chick limb. Development 124: 4547-4556.

Aono, $\mathrm{H}$. and $\mathrm{H}$. Ide. 1988. A gradient of responsiveness to the growth-promoting activity of ZPA (zone of polarizing activity) in the chick limb bud. Dev. Biol. 128: 136-141.

Armelin, H.A. 1973. Pituitary extracts and steroid hormones in the control of 3 T 3 cell growth. Proc. Natl. Acad. Sci. 70: 2702-2706.

Baird, A. 1994. Fibroblast growth factors: Activities and significance of non-neurotrophin neurotrophic growth factors. Curr. Opin. Neurobiol. 4: 78-86.

Basilico, C. and D. M oscatelli. 1992. The FGF family of growth factors and oncogenes. Adv. Cancer Res. 59: 115-165.

Bellusci, S., J. Grindley, H. Emoto, N. Itoh, and B.L. Hogan. 1997. Fibroblast Growth Factor 10 (FGF10) and branching morphogenesis in the embryonic mouse lung. Development 124: 4867-4878.

Bishop-Calame, S. 1965. N ouvelles recherches concernant le rôle du canal de Wolff dans la différentiation du mésonéphros de l'embryon de poulet. J. Embryol. Exp. Morphol. 14: 239-245.

Brook, W.J., F.J. Diaz-Benjumea, and S.M. Cohen. 1997. Organizing spatial pattern in limb development. Annu. Rev. Cell Dev. Biol. 12: 161-180.

Burdine, R.D., E.B. Chen, S.F. Kwok, and M .J. Stern. 1997. egl-17 encodes an invertebrate fibroblast growth factor family member required specifically for sex myoblast migration in Caenorhabditis elegans. Proc. Natl. Acad. Sci. 94: 24332437.

Burdine, R.D., C.S. Branda, and M.J. Stern. 1998. EGL-17 (FGF) expression coordinates the attraction of the migrating sex myoblasts with vulval induction in C. elegans. Development 125: 1083-1093.

Carrington, J.L. and J.F. Fallon. 1984. The stages of flank ectoderm capable of responding to ridge induction in the chick embryo. J. Embryol. Exp. Morphol. 84: 19-34.

Chan, D.C., A. Wynshaw-Boris, and P. Leder. 1995. Formin isoforms are differentially expressed in the mouse embryo and are required for normal expression of fgf- 4 and shh in the limb bud. Development 121: 3151-3162.

Chang, D.T., A. López, D.P. von Kessler, C. Chiang, B.K. Simandl, R. Zhao, M.F. Seldin, J.F. Fallon, and P.A. Beachy. 1994. Products, genetic linkage and limb patterning activity of a murine hedgehog gene. Devel opment 120: 3339-3353.

Charité, J., W. de Graff, S. Shen, and J. Deschamps. 1994. Ectopic expression of Hoxb-8 causes duplication of the ZPA in the forelimb and homeotic transformation of axial structures. Cell 78: 589-601.

Chevallier, A., M. Kieny, and A. Mauger. 1977. Limb-somite relationship: Origin of the limb musculature. J. Embryol. Exp. Morphol. 41: 245-258.

Chiang, C., Y. Litingtung, E. Lee, K.E. Young, J.L. Cordoen, H. Westphal, and P.A. Beachy. 1996. Cyclopia and axial patterning in mice lacking Sonic hedgehog gene function. Nature 383: 407-413.

Christ, B., H.J. Jacob, and M. Jacob. 1977. Experimental analysis of the origin of the wing musculature in avian embryos. 
Anat. Embryol. 150: 171-186.

Cohen, B., A. Bashirullah, L. Dagnino, C. Campbell, W.W. Fisher, C.C. Leow, E. Whiting, D. Ryan, D. Zinyk, G. Boulianne, C.-C. Hui, B. Gallie, R.A. Phillips, H.D. Lipshitz, and S.E. Egan. 1997. Fringe boundaries coincide with $\mathrm{N}$ otch-dependent patterning centres in mammals and alter $\mathrm{N}$ otchdependent development in Drosophila. Nature Genet. 16: 283-288.

Cohn, M.J., J.-C. Izpisúa-Belmonte, H. A bud, J.K. Heath, and C. Tickle. 1995. Fibroblast growth factors induce additional limb development from the flank of chick embryos. Cell 80: 739-746.

Cohn, M.J., K. Patel, R. Krumlauf, D.G. Wilkinson, J.D. Clarke, and C. Tickle. 1997. Hox9 genes and vertebrate limb specification. Nature 387: 97-101.

Coulier, F., P. Pontarotti, R. Roubin, H. Hartung, M. Goldfarb, and D. Birnbaum. 1997. Of worms and men: An evolutionary perspective on the fibroblast growth factor (FGF) and FGF receptor families. J. Mol. Evol. 44: 43-56.

Crossley, P.H. and G.R. Martin. 1995. The mouse Fgf8 gene encodes a family of polypeptides and is expressed in regions that direct outgrowth and patterning in the developing embryo. Development 121: 439-451.

Crossley, P.H., G. Minowada, C.A. MacArthur, and G.R. Martin. 1996. Roles for FGF8 in the induction, initiation, and maintenance of chick limb development. Cell 84: 127-136.

Cygan, J.A., R.L. Johnson, and A.P. McMahon. 1997. Novel regulatory interactions revealed by studies of murine limb pattern in Wnt-7a and En-1 mutants. Development 124: 5021-5032.

Davis, C.A., D.P. Holmyard, K.J. Millen, and A.L. Joyner. 1991. Examining pattern formation in mouse, chicken and frog embryos with an En-specific antiserum. Development 111: 287-298.

de Lapeyrière, O., V. Ollendorff, J. Planche, M.O. Ott, S. Pizette, F. Coulier, and D. Birnbaum. 1993. Expression of the Fgf6 gene is restricted to devel oping skel etal muscle in the mouse embryo. Development 118: 601-611.

De Moerlooze, L. and C. Dickson. 1997. Skeletal disorders associated with fibroblast growth factor receptor mutations. Curr. Opin. Genet. Dev. 7: 378-385.

Dealy, C.N., A. Roth, D. Ferrari, A.M.C. Brown, and R.A. Kosher. 1993. Wnt-5a and Wnt-7a are expressed in the developing chick limb bud in a manner suggesting roles in pattern formation along the proximodistal and dorsoventral axes. Mech. Dev. 43: 175-186.

Dealy, C.N., K. Clarke, and V. Scranton. 1996. Ability of FGFs to promote the outgrowth and proliferation of limb mesoderm is dependent on IGF-I activity. Dev. Dyn. 206: 463469.

Dealy, C.N., M.R. Seghatoleslami, D. Ferrari, and R.A. Kosher. 1997. FGF-stimulated outgrowth and proliferation of limb mesoderm is dependent on syndecan-3. Dev. Biol. 184: 343350.

Deng, C., M. Bedford, C. Li, X. Xu, X. Yang, J. Dunmore, and P. Leder. 1997. Fibroblast growth factor receptor-1 (FGFR-1) is essential for normal neural tube and limb devel opment. Dev. Biol. 185: 42-54.

Drucker, B.J. and M. Goldfarb. 1993. M urine FGF-4 gene expression is spatially restricted within embryonic skel etal muscle and other tissues. Mech. Dev. 40: 155-163.

Duboule, D. 1995. Vertebrate Hox genes and proliferation: An alternative pathway to homeosis? Curr. Opin. Genet. Dev. 5: 525-528.

Duprez, D.M., K. Kostakopoulou, P.H. Francis-West, C. Tickle, and P.M. Brickell. 1996. Activation of Fgf-4 and HoxD gene expression by BMP-2 expressing cells in the developing chick limb. Development 122: 1821-1828.

Faham, S., R.E. Hileman, J.R. Fromm, R.J. Linhardt, and D.C. Rees. 1996. Heparin structure and interactions with basic fibroblast growth factor. Science 271: 1116-1120.

Fallon, J.F., A. López, M.A. Ros, M.P. Savage, B.B. Olwin, and B.K. Simandl. 1994. FGF-2: A pical ectodermal ridge growth signal for chick limb development. Science 264: 104-107.

Fantl, W.J., K.G. Peters, and L.T. Williams. 1996. PDGF and FGF receptors in health and disease. In Growth factors and cytokines in health and disease (ed. D. Leroith and C. Bondy), pp. 179-228. JAI Press, London, UK.

Feldman, B., W. Poueymirou, V.E. Papaioannou, T.M. DeChiara, and M. Goldfarb. 1995. Requirement of FGF-4 for postimplantation mouse development. Science 267: 246249.

Fernandez-Teran, M., M.E. Piedra, B.K. Simandl, J.F. Fallon, and M.A. Ros. 1997. Limb initiation and development is normal in the absence of the mesonephros. Dev. Biol. 189: 246-255.

Geduspan, J.S. and M. Solursh. 1992. A growth-promoting influence from the mesonephros during limb outgrowth. Dev. Biol. 151: 212-250.

Goetinck, P.F. and U.K. A bbott. 1964. Studies on limb morphogenesis. I. Experiments with the polydactylous mutant, Talpid2. J. Exp. Zool. 155: 161-170.

Goldfarb, M. 1996. Functions of fibroblast growth factors in vertebrate development. Cytokine Growth Factor Rev. 7: 311-325.

Gospodarowicz, D. 1974. Local isation of a fibroblast growth factor and its effect al one and with hydrocortisone on $3 T 3$ cell growth. Nature 249: 123-127.

Green, P.J., F.S. Walsh, and P. Doherty. 1996. Promiscuity of fibroblast growth factor receptors. BioEssays 18: 639-646.

Grieshammer, U., G. Minowada, J.M. Pisenti, U.K. Abbott, and G.R. M artin. 1996. The chick limbless mutation causes abnormalities in limb bud dorsal-ventral patterning: Implications for the mechanism of apical ridge formation. Development 122: 3851-3861.

Gu, H., J.D. M arth, P.C. Orban, H. M ossmann, and K. Rajewsky. 1994. Deletion of a DNA polymerase $\beta$ gene segment in T cells using cell type-specific gene targeting. Science 265: 103-106.

Hacohen, N., S. Kramer, D. Sutherland, Y. Hiromi, and M.A. Krasnow. 1998. sprouty encodes a novel antagonist of FGF signaling that patterns apical branching of the Drosophila airways. Cell 92: 253-263.

Hammerschmidt, M., A. Brook, and A.P. McM ahon. 1997. The world according to hedgehog. Trends Genet. 13: 14-21.

Han, J.-K. and G.R. M artin. 1993. Embryonic expression of Fgf-6 is restricted to the skeletal muscle lineage. Dev. Biol. 158: 549-554.

Haramis, A.G., J.M. Brown, and R. Zeller. 1995. The limb deformity mutation disrupts the SHH/FGF-4 feedback loop and regulation of $5^{\prime}$ HoxD genes during limb pattern formation. Development 121: 4237-4245.

Hartung, H., B. Feldman, H. Lovec, F. Coulier, D. Birnbaum, and M. Goldfarb. 1997. Murine FGF-12 and FGF-13: Expression in embryonic nervous system, connective tissue and heart. Mech. Dev. 64: 31-39.

Haub, O. and M. Goldfarb. 1991. Expression of the fibroblast growth factor-5 gene in the mouse embryo. Development 112: 397-406.

Heikinheimo, M., A. Lawshé, G.M. Shackleford, D.B. Wilson, and C.A. MacArthur. 1994. Fgf-8 expression in the post-gastrulation mouse suggests roles in the development of the face, limbs, and central nervous system. Mech. Dev. 48: 129- 
138

Hinchliffe, J.R. and D.R. Johnson. 1980. The development of the vertebrate limb: An approach through experiment, genetics, and evolution. Clarendon Press, Oxford, UK.

Hogan, B.L. 1996. Bone morphogenetic proteins: Multifunctional regulators of vertebrate development. Genes \& Dev. 10: 1580-1594.

Hornbruch, A. and L. Wolpert. 1991. The spatial and temporal distribution of polarizing activity in the flank of the prelimb-bud stages in the chick embryo. Development 111: 725-731.

Hoshikawa, M., N. Ohbayashi, A. Yonamine, M. Konishi, K. Ozaki, S. Fukui, and N. Itoh. 1998. Structure and expression of a novel fibroblast growth factor, FGF-17, preferentially expressed in the embryonic brain. Biochem. Biophys. Res. Comm. (in press).

Irvine, K.D. and T.F. Vogt. 1997. Dorsal-ventral signaling in limb development. Curr. Opin. Cell Biol. 9: 867-876.

Johnson, D.E. and L.T. Williams. 1993. Structural and functional diversity in the FGF receptor multigene family. Adv. Cancer Res. 60: 1-41.

Johnson, R.L. and C.J. Tabin. 1997. Molecular models for vertebrate limb development. Cell 90: 979-990.

Johnston, S.H., C. Rauskolb, R. Wilson, B. Prabhakaran, K.D. Irvine, and T.F. Vogt. 1997. A family of mammalian Fringe genes implicated in boundary determination and the $\mathrm{N}$ otch pathway. Development 124: 2245-2254.

Kieny, M. 1969. Sur les rel ations entre le mésoderme somitique et le mésoderme somatopleural avant et au course de l'induction primoire des membres de l'embryon de Poulet. C. R. Acad. Sci. Paris 268: 3183-3186.

_-_. 1970. Le rôle du mésoderme somitique dans la morphogenèse précoce des membres de l'embryon de poulet. J. Embryol. Exp. Morphol. 23: 109-151.

Kilby, N.J., M.R. Snaith, and J.A. Murray. 1993. Site-specific recombinases: Tools for genome engineering. Trends $G$ enet. 9: 413-421.

Kuhlman, J. and N. Niswander. 1997. Limb deformity proteins: Role in mesodermal induction of the apical ectodermal ridge. Development 124: 133-139.

Laufer, E., C.E. N elson, R.I. Johnson, B.A. M organ, and C. Tabin. 1994. Sonic hedgehog and Fgf-4 act through a signaling cascade and feedback loop to integrate growth and patterning of the developing limb bud. Cell 79: 993-1003.

Laufer, E., R. Dahn, O.E. Orozco, C.-Y. Yeo, J. Pisenti, D. Henrique, U.K. Abbott, J.F. Fallon, and C. Tabin. 1997. Expression of Radical fringe in limb-bud ectoderm regulates apical ectodermal ridge formation. Nature 386: 366-373.

Le Douarin, N. and J. Fontaine. 1970. Limites du territoire pronèphritique capable de s'autodifferéncier et de fournir l'ebauche primitive du canal de Wolff chez l'embryon de poulet. C. R. Acad. Sci. Paris 270: 1708-1711.

Lee, J. and C. Tickle. 1985. Retinoic acid and pattern formation in the developing chick wing: SEM and quantitative studies of early effects on the apical ectodermal ridge and bud outgrowth. J. Embryol. Exp. Morphol. 90: 139-169.

Liu, J.P., J. Baker, A.S. Perkins, E.J. Robertson, and A. Efstratiadis. 1993. Mice carrying null mutations of the genes encoding insulin-like growth factor I (Igf-1) and type 1 IG F receptor (Igf1r). Cell 75: 59-72.

Logan, C., A. Hornbruch, I. Campbell, and A. Lumsden. 1997. The role of Engrailed in establishing the dorsoventral axis of the chick limb. Development 124: 2317-2324.

Loomis, C.A., E. Harris, J. Michaud, W. Wurst, M. Hanks, and A.L. Joyner. 1996. The mouse Engrailed-1 gene and ventral limb patterning. Nature 382: 360-363.
Loomis, C.A., R.A. Kimmel, C.-X. Tong, J. Michaud, and A.L. Joyner. 1998. A nalysis of the genetic pathway leading to formation of ectopic apical ectoderm ridges in mouse Engrailed-1 mutant limbs. Development 125: 1137-1148.

Lu, H.-C., J.-P. Revelli, L. Goering, C. Thaller, and G. Eichele. 1997. Retinoic signaling is required for the establishment of a ZPA and for the expression of HoxB-8, a mediator of ZPA formation. Development 124: 1643-1651.

M acCabe, J.A., J. Errick, and J.W. Saunders Jr. 1974. Ectodermal control of the dorsoventral axis in the leg bud of the chick embryo. Dev. Biol. 39: 69-82.

M acCabe, J.A., A.B. M acCabe, U.K. A bbott, and J.R. McCarrey. 1975. Limb development in Diplopodia4: A polydactylous mutation in the chicken. J. Exp. Zool. 191: 383-394.

Mahmood, R., J. Bresnick, A. Hornbruch, C. Mahony, N. Morton, K. Colquhoun, P. M artin, A. Lumsden, C. Dickson, and I. Mason. 1995a. A role for FGF-8 in the initiation and maintenance of vertebrate limb bud outgrowth. Curr. Biol. 5: 797-806.

M ahmood, R., P. Kiefer, S. Guthrie, C. Dickson, and I. Mason. 1995b. Multiple roles for FGF-3 during cranial neural development in the chicken. Development 121: 1399-1410.

Marcelle, C., A. Eichmann, O. Halevy, C. Bréant, and N.M. Le Douarin. 1994. Distinct developmental expression of a new avian fibroblast growth factor receptor. Development 120: 683-694.

Martin, P. 1990. Tissue patterning in the developing mouse limb. Int. J. Dev. Biol. 34: 323-336.

Mason, I. 1994. The ins and outs of fibroblast growth factors. Cell 78: 547-552.

Mason, I., F. Fuller-Pace, R. Smith, and C. Dickson. 1994. FGF-7 (keratinocyte growth factor) expression during mouse development suggests roles in myogenesis, forebrain regionalization and epithelial-mesenchymal interactions. Mech. Dev. 45: 15-30.

McWhirter, J.R., M. Goulding, J.A. Weiner, J. Chun, and C. M urre. 1997. A novel fibroblast growth factor gene expressed in the devel oping nervous system is a downstream target of the chimeric homeodomain oncoprotein E2A-Pbx1. Development 124: 3221-3232.

Meinhardt, H. 1983. A boundary model for pattern formation in vertebrate limbs. J. Embryol. Exp. Morphol. 76: 115-137.

Meyers, E.N., M. Lewandoski, and G.R. Martin. 1998. Generation of an Fgf8 mutant allelic series using a single targeted mouse line carrying $\mathrm{Cre}$ and $\mathrm{Flp}$ recombinase recognition sites. Nature Genet. 18: 136-141.

Michaud, J.L., F. Lapointe, and N.M. Le Douarin. 1997. The dorsoventral polarity of the presumptive limb is determined by signals produced by the somites and by the lateral somatopleure. Development 124: 1453-1463.

Milaire, J. 1974. Limb morphogenesis. In Handbuch der histochemie, pp. 38-60. Gustav Fischer Verlag, Stuttgart, Germany.

Mima, T., H. Ohuchi, S. Noji, and T. Mikawa. 1995. FGF can induce outgrowth of somatic mesoderm both inside and outside of limb-forming regions. Dev. Biol. 167: 617-620.

Miyake, A., M. Konishi, F.H. Martin, N.A. Hernday, K. Ozaki, S. Yamamoto, T. Mikami, T. Arakawa, and N. Itoh. 1998. Structure and expression of a novel member, FGF-16, of the Fibroblast Growth Factor family. Biochem. Biophys. Res. Commun. 243: 148-152.

Niswander, L., S. Jeffrey, G.R. Martin, and C. Tickle. 1994. A positive feedback loop coordinates growth and patterning in the vertebrate limb. Nature 371: 609-612.

Niswander, L. and G.R. Martin. 1992. Fgf-4 expression during gastrulation, myogenesis, limb and tooth development in 
the mouse. Development 114: 755-768.

- - - 1993. FGF-4 and BM P-2 have opposite effects on limb growth. Nature 361: 68-71.

Niswander, L., C. Tickle, A. Vogel, I. Booth, and G.R. Martin. 1993. FGF-4 replaces the apical ectodermal ridge and directs outgrowth and patterning of the limb. Cell 75: 579-587.

N oramly, S., J. Pisenti, U. Abbott, and B. Morgan. 1996. Gene expression in the limbless mutant: Pol arized gene expression in the absence of Shh and an AER. Dev. Biol. 179: 339-346.

Ohuchi, H., H. Yoshioka, A. Tanaka, Y. Kawakami, T. N ohno, and S. N oji. 1994. Involvement of androgen-induced growth factor (FGF-8) gene in mouse embryogenesis and morphogenesis. Biochem. Biophys. Res. Commun. 204: 882-888.

Ohuchi, H., T. Nakagawa, M. Yamauchi, T. Ohata, H. Yoshioka, T. Kuwana, T. Mima, T. Mikawa, T. N ohno, and S. N oji. 1995. An additional limb can be induced from the flank of the chick embryo by FGF4. Biochem. Biophys. Res. Commun. 209: 809-816.

Ohuchi, H., T. N akagawa, A. Yamamoto, A. Araga, T. Ohata, Y. Ishimaru, H. Yoshioka, T. Kuwana, T. N ohno, M. Yamasaki, N. Itoh, and S. N oji. 1997. The mesenchymal factor, FGF10, initiates and maintains the outgrowth of the chick limb bud through interaction with FGF8, an apical ectodermal factor. Development 124: 2235-2244.

Ohuchi, H., J. Takeuchi, H. Yoshioka, I. Yoshiyasu, K. Ogura, N. Takahashi, T. Ogura, and S. N oji. 1998. Correlation of wing-leg identity in ectopic FGF-induced chimeric limbs with the differential expression of chick Tbx5 and Tbx4. Development 125: 51-60.

Ohsugi, K., D.M. Gardiner, and S.V. Bryant. 1997. Cell cycle length affects gene expression and pattern formation in limbs. Dev. Biol. 189: 13-21.

Orr-Urtreger, A., D. Givol, A. Yayon, Y. Yarden, and P. Lonai. 1991. Developmental expression of two murine fibroblast growth factor receptors, flg and bek. Development 113: 1419-1434.

Orr-U rtreger, A., M.T. Bedford, T. Burakova, E. Arman, Y. Zimmer, A. Yayon, D. Givol, and P. Lonai. 1993. Devel opmental localization of the splicing al ternatives of fibroblast growth factor receptor-2 (FGFR2). Dev. Biol. 158: 475-486.

Parr, B.A. and A.P. M CM ahon. 1994. Wnt genes and vertebrate development. Curr. Opin. Genet. Dev. 4: 523-528.

- - . 1995. Dorsalizing signal Wnt-7a required for normal polarity of D-V and A-P axes of mouse limb. Nature 374: 350353.

Parr, B.A., M.J. Shea, G. Vassileva, and A.P. McM ahon. 1993. M ouse Wnt genes exhibit discrete domains of expression in the early embryonic CNS and limb buds. Development 119: $247-261$.

Pautou, M.P. 1977. Dorso-ventral axis determination of chick limb bud development. In Vertebrate limb and somite morphogenesis (ed. D.A. Ede, J. R. Hinchliffe, and M. Balls), pp. 257-266. Cambridge University Press, Cambridge, UK.

Peters, K.G., S. Werner, G. Chen, and L.T. Williams. 1992. Two FGF receptor genes are differentially expressed in epithelial and mesenchymal tissues during limb formation and organogenesis in the mouse. Development 114: 233-243.

Peters, K., D. Ornitz, S. Werner, and L. Williams. 1993. Unique expression pattern of the FGF receptor 3 gene during mouse organogenesis. Dev. Biol. 155: 423-430.

Pinot, M. 1970. Le rôle du mésoderme somitique dans la morphogenèse précoce des membres de l'embryon de poulet. J. Embryol. Exp. Morphol. 23: 109-151.

Qu, S., K.D. Niswender, Q. Ji, R. van der M eer, D. Keeney, M.A. Magnuson, and R. Wisdom. 1997. Polydactyly and ectopic ZPA formation in Alx-4 mutant mice. Development
124: 3999-4008.

Riddle, R.D., R.L. Johnson, E. Laufer, and C. Tabin. 1993. Sonic hedgehog mediates the polarizing activity of the ZPA. Cell 75: 1401-1416.

Riddle, R.D., M. Ensini, C. N elson, T. Tsuchida, T.M. Jessell, and C. Tabin. 1995. Induction of the LIM homeobox gene $\mathrm{Lm \times 1}$ by Wnt7a establishes dorsoventral pattern in the vertebrate limb. Cell 83: 631-640.

Riley, B.B., M.P. Savage, B.K. Simandl, B.B. Olwin, and J.F. FalIon. 1993. Retroviral expression of FGF-2 (bFGF) affects patterning in chick limb bud. Development 118: 95-104.

Rodriguez-Esteban, C., J.W.R. Schwabe, J. De La Peña, B. Foys, B. Eshelman, and J.-C. Izpisúa-Belmonte. 1997. Radical fringe positions the apical ectodermal ridge at the dorsoventral boundary of the vertebrate limb. Nature 386: 360-365.

Ros, M.A., A. López-M artínez, B.K. Simandl, C. Rodriguez, J.-C. Izpisúa-Belmonte, R. Dahn, and J.F. Fallon. 1996. The limb field mesoderm determines initial limb bud anteroposterior asymmetry and budding independent of sonic hedgehog or apical ectodermal gene expressions. Development 122: 2319-2330.

Rubin, L. and J.W. Saunders Jr. 1972. Ectodermal-mesodermal interactions in the growth of limb buds in the chick embryo: Constancy and temporal limits of the ectodermal induction. Dev. Biol. 28: 94-112.

Sakamoto, K., L. Yan, H. Imai, M. Takagi, Y. Nabeshima, S. Takeda, and K. Katsube. 1997. Identification of a chick homologue of Fringe and C-Fringe 1: Involvement in the neurogenesis and the somitogenesis. Biochem. Biophys. Res. Commun. 234: 754-759.

Saunders, J.W., Jr. 1948. The proximo-distal sequence of the origin of the parts of the chick wing and the role of the ectoderm. J. Exp. Zool. 108: 363-403.

Saunders, J.W. and M.T. Gasseling. 1968. Ectoderm-mesenchymal interactions in the origin of wing symmetry. In Epithelial-mesenchymal interactions (ed. R. Fleischmajer and R. E. Billingham), pp. 78-97. Williams and Wilkins, Baltimore, MD.

Savage, M.P. and J.F. Fallon. 1995. FGF-2 mRNA and its antisense message are expressed in a developmentally specific manner in the chick limb bud and mesonephros. Dev. Dyn. 202: 343-353.

Searls, R.L. and M.Y. Janners. 1971. The initiation of limb bud outgrowth in the embryonic chick. Dev. Biol. 24: 198-213.

Sidow, A., M.S. Bulotsky, A.W. Kerrebrock, R.T. Bronson, M.J. Daly, M.P. Reeve, T.L. Hawkins, B.W. Birren, R. Jaenisch, and E.S. Lander. 1997. Serrate2 is disrupted in the mouse limb-development mutant syndactylism. Nature 389: 722725.

Smallwood, P.M., I. M unoz-Sanjuan, P. Tong, J.P. Macke, S.H. Hendry, D.J. Gilbert, N.G. Copeland, N.A. Jenkins, and J. N athans. 1996. Fibroblast growth factor (FGF) homologous factors: $\mathrm{N}$ ew members of the FGF family implicated in nervous system devel opment. Proc. Natl. Acad. Sci. 93: 98509857.

Stark, K.L., J.A. M CM ahon, and A.P. M CM ahon. 1991. FGFR-4, a new member of the fibroblast growth factor receptor family expressed in the definitive endoderm and skeletal muscle lineages of the mouse. Development 113: 641-651.

Stephens, T.D. and T.R. McN ulty. 1981. Evidence for a metameric pattern in the development of the chick humerus. J. Embryol. Exp. Morphol. 61: 191-205.

Stephens, T.D., S.G. Roberts, R.J. Marchiando, L.L. Degn, D.A. Hackett, M.A. Warnock, M.J. Mason, D.R. Edwards, R.D. Torres, P.K. Deriemaeker, J.J. Slatosky, and D.J. Yingst. 1993. Axial and paraxial influences on the origin of the chick 
embryo limb. In Limb development and regeneration (ed. J. Fallon, R. Kelley, P. Goetinck, and D. Stocum), pp. 317-326. Wiley-Liss, New York, NY.

Stratford, T.H., K. Kostakopoulou, and M. M aden. 1997. Hoxb-8 has a role in establishing early anterior-posterior polarity in chick forelimb but not hindlimb. Development 124: 42254234.

Strecker, T.R. and T.D. Stephens. 1983. Peripheral nerves do not play a trophic role in limb skeletal morphogenesis. Teratology 27: 159-167.

Summerbell, D. 1974. A quantitative analysis of the effect of excision of the AER from the chick limb bud. J. Embryol. Exp. Morphol. 32: 651-660.

Summerbell, D., J.H. Lewis, and L. Wolpert. 1973. Positional information in chick limb morphogenesis. Nature 224: 492496.

Sutherland, D., C. Samakovlis, and M.A. Krasnow. 1996. branchless encodes a Drosophila FGF homolog that controls tracheal cell migration and the pattern of branching. Cell 87: 1091-1101.

Suzuki, H.R., H. Sakamoto, T. Yoshida, T. Sugimura, M. Terada, and M. Solursh. 1992. Localization of Hst1 transcripts to the apical ectodermal ridge in the mouse embryo. Dev. Biol. 150: 219-222.

Tanaka, M., K. Tamura, S. N oji, T. N ohno, and H. Ide. 1997. Induction of additional limb at the Dorsal-Ventral boundary of a chick embryo. Dev. Biol. 182: 191-203.

Tickle, C. and G. Eichele. 1994. Vertebrate limb development. Annu. Rev. Cell Biol. 10: 121-152.

Todt, W.L. and J.F. Fallon. 1984. Development of the apical ectodermal ridge in the chick wing bud. J. Embryol. Exp. Morphol. 80: 21-41.

Vargesson, N., J.D.W. Clarke, K. Vincent, C. Coles, L. Wol pert, and C. Tickle. 1997. Cell fate in the chick limb bud and relationship to gene expression. Development 124: 19091918.

Vogel, A. and C. Tickle. 1993. FGF-4 maintains polarizing activity of posterior limb bud cells in vivo and in vitro. Development 119: 199-206.

Vogel, A., C. Rodriguez, W. Warnken, and J.-C. Izpisúa-Belmonte. 1995. Dorsal cell fate specified by chick Lmx1 during vertebrate limb devel opment. N ature 378: 716-720.

Vogel, A., C. Rodriguez, and J.-C. Izpisúa-Belmonte. 1996. Involvement of FGF-8 in initiation, outgrowth and patterning of the vertebrate limb. Development 122: 1737-1750.

Webster, M.K. and D.J. Donoghue. 1997. FGFR activation in skel etal disorders: Too much of a good thing. Trends Genet. 13: 178-182.

Wilkie, A.O., G.M. Morriss-Kay, E.Y. Jones, and J.K. Heath. 1995. Functions of fibroblast growth factors and their receptors. Curr. Biol. 5: 500-507.

Wilkinson, D.G., G. Peters, C. Dickson, and A.P. McMahon. 1988. Expression of the FGF-related proto-oncogene Int-2 during gastrulation and neurulation in the mouse. EMBO J. 7: 691-695.

Wilkinson, D.G., S. Bhatt, and A.P. M cM ahon. 1989. Expression of the FGF-related proto-oncogene Int-2 suggests multiple roles in fetal development. Development 105: 131-136.

Wolff, E. 1970. Inductive mechanisms in kidney organogenesis. In Tissue interactions during organogenesis (ed. E. Wolff), pp. 17-35. Gordon and Breach, N ew York, NY.

Wu, J.Y., L. Wen, W.J. Zhang, and Y. Rao. 1996. The secreted product of $X$ enopus gene lunatic Fringe, a vertebrate signaling molecule. Science 273: 355-358.

Xu, X., M. Weinstein, C. Li, M. N aski, R.I. Cohen, D.M. Ornitz, P. Leder, and C. Deng. 1998. Fibroblast growth factor recep- tor 2 (FGFR2) mediated reciprocal regulation loop between FGF8 and FGF10 is essential for limb induction. Development 125: 767-775.

Yamaguchi, T.P. and J. Rossant. 1995. Fibroblast growth factors in mammalian development. Curr. Opin. Genet. Dev. 5: 485-491.

Yang, Y. and L. N iswander. 1995. Interaction between the signaling molecules Wnt7a and $\mathrm{SHH}$ during vertebrate limb development: Dorsal signals regulate anteroposterior patterning. Cell 80: 939-947.

Zhou, M., R.L. Sutliff, R.J. Paul, J.N . Lorenz, J.B. Hoying, C.C. Haudenschild, M. Yin, J.D. Coffin, L. Kong, E.G. Kranias, W. Luo, G.P. Boivin, J.J. Duffy, S.A. Pawlowski, and T. Doetschman. 1998. Fibroblast growth factor 2 control of vascular tone. Nature Med. 4: 201-207.

Zhu, X., H. Komiya, A. Chirino, S. Faham, G.M. Fox, T. Arakawa, B.T. Hsu, and D.C. Rees. 1991. Three-dimensional structures of acidic and basic fibroblast growth factors. Science 251: 90-93.

Zwilling, E. 1956. Interaction between limb bud ectoderm and mesoderm in the chick embryo. I. Axis establishment. J. Exp. Zool. 132: 157-171. 


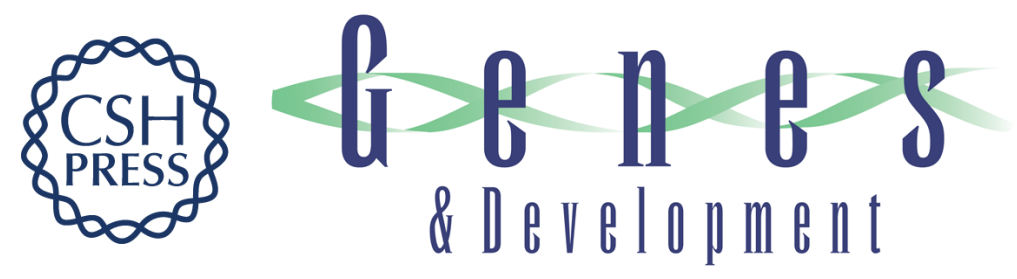

\section{The roles of FGFs in the early development of vertebrate limbs}

Gail R. Martin

Genes Dev. 1998, 12:

Access the most recent version at doi:10.1101/gad.12.11.1571

References This article cites 142 articles, 49 of which can be accessed free at: http://genesdev.cshlp.org/content/12/11/1571.full.html\#ref-list-1

License

Email Alerting Receive free email alerts when new articles cite this article - sign up in the box at the top Service right corner of the article or click here.

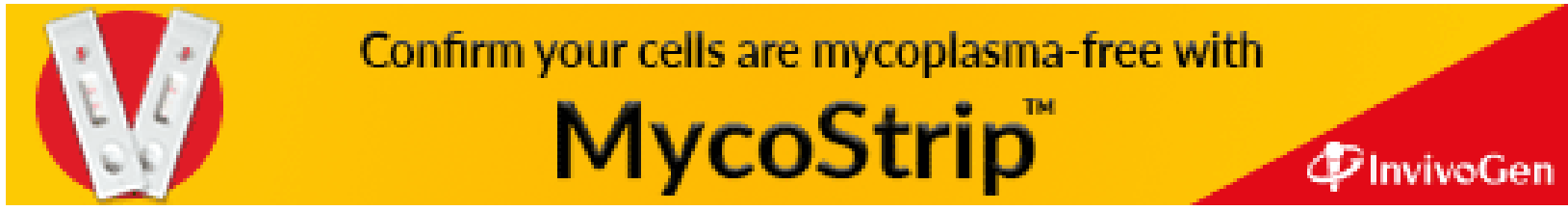

